Amasya Ilahiyat Dergisi - Amasya Theology Journal

ISSN 2667-7326 | e-ISSN 2667-6710

Aralık / December 2020, 15: 517-547

\title{
Rivayetlerle Fıkhî Zâbıtaların Etkileşimi: Meninin Necaseti Örneği
}

\section{Fikret ÖZÇELIKK}

Dr. Öğr. Üyesi, Mardin Artuklu Üniversitesi, İslami İlimler Fakültesi, Hadis Anabilim Dalı

Assistant Professor, Mardin Artuklu University, Faculty of İslamic Sciences,

Department of Hadith

Mardin, Turkey

ozcelik.21@hotmail.com

orcid.org/0000-0001-5015-6167

\section{Makale Bilgisi / Article Information}

Makale Türü / Article Types: Araştırma Makalesi / Research Article

Geliş Tarihi / Received: 12 Eylül / September 2020

Kabul Tarihi / Accepted: 02 Kasım / November 2020

Yayın Tarihi / Published: 30 Aralık / December 2020

Yayın Sezonu / Pub. Date Season: Aralık / December

Sayı / Issue: 15 Sayfa / Pages: 517-547

Atıf / Cite as: Özçelik, Fikret. "Rivayetlerle Fıkhî Zâbıtaların Etkileşimi: Meninin Necaseti Örneği [Transaction of Jurisprudential (Fiqhî) Specific Rules with Narrations: Example of Semen as Dirt]". Amasya Illahiyat Dergisi-Amasya Theology Journal 15 (December 2020): 517-547.

https://doi.org/10.18498/amailad.794099.

Intihal / Plagiarism: Bu makale, en az iki hakem tarafından incelendi ve intihal içermediği teyit edildi. / This article has been reviewed by at least two referees and scanned via a plagiarism software.

Copyright $\odot$ Published by Amasya Üniversitesi, İlahiyat Fakültesi / Amasya University, Faculty of Theology, Amasya, 05100 Turkey. All rights reserved. https://dergipark.org.tr/amailad. 
518 | F. ÖZÇELIK / Rivayetlerle Fıkhî Zâbıtaların Etkileşimi: Meninin Necaseti Örneği

\section{Transaction of Jurisprudential (Fiqhî) Specific Rules with Narrations: Example of Semen as Dirt}

\section{Abstract}

One of the controversies issues related to Hadith science is associated with the criteria to accept the narrations as authentic or weak. Within this context, it is a fact that various methods have been used to understand, evaluate and determine the authenticity of the narrations. Because of this fact that different approaches have been raised in understanding and interpreting the hadiths since the early period. In relation to this, it has also become inevitable that different views and sects emerged. On the other hand, the Qur'an, sunnah and ijtihad, which are universal rules and jurisprudential specific rules, have developed and systematized as a separate genre in classical fiqh literature. Also, it is seen that the scholars concluded different results about narrations the accepting a hadith as authentic and put forward some jurisprudential specific rules while making inferences (istinbât) on the issue as a result of different understanding in understanding and interpreting the hadiths.

In this study, it is aimed to investigate the narrations about semen as dirt within the context of jurisprudential specific rules. Firstly, the narrations on the subject in the basic hadiths sources were determined. The authenticity status of these determined narrations were explained in terms of isnad. Then, the interpretations that especially sect imams and scholars made on these narrations in terms of jurisprudential specific rules were mentioned. Also, the effects of narrations on the jurisprudential specific rules were also pointed out. As a result of the investigations carried out, more than one narration about semen was identified, and it was seen that these narrations were authentic in terms of isnad. In addition, it was established that the content of the narrations is the washing and rubbing the semen. As far as it was determined, there is no statement directly belonging to Prophet about semen as dirt (najis). In this case, it was seen that scholars interpreted the narrations within the framework of jurisprudential specific rules that they developed and found some inferences (istinbat).

According to Hanafis, semen is najis whether it is wet or dry in all cases. They tried to prove their views with jurisprudential specific rules as well as some narrated evidences as "Whatever causes dirt is najis in its own right.". Likewise, Hanafis said that semen is najis by comparing it to urine and menstruation blood. It is seen that Hanafis, who accept the Ferk narration, prioritized the jurisprudential specific rules about the issue that semen is najis. In addition to this, in the Hanafi sect, "it is wajib to wash away something najis" is a well- 
known jurisprudential specific rule. However, Hanafis made an exception when the semen was dry; and they found it sufficient to rub the dry semen away. So, the narration was preferred to jurisprudential specific rule.

Mâlik b. Enes accepted semen as najis and claimed that it must be washed. In addition, Mâlik did not consider the rubbing as sufficient; and he did not accept such an application. In Shafi'îte sect, such a jurisprudential specific rule is valid as "Every liquid discharged from front or back of a person is najis." According to this, feces, urine, blood and semen are to be accepted as najis. However, semen was exempted from this jurisprudential specific rule, and considered as clean. They put forward some logical evidences, comparisons and ferk narration narrated by Aisha as a justification. That is to say that Shafi'îtes preferred the narration to their general principles.

Ahmad b. Hanbal also said that semen was clean. Those, who consider the sufficient to rub away the semen, accepted the narrations expressing that the semen should be washed away as authentic. According to them, rubbing act was performed not for the fact that semen is najis, but it was like cleaning mubah things such as saliva and soil. Based on this particular example, it is understood that the narrations affect the jurisprudential specific rules, and at the same time the jurisprudential specific rules are also effective in understanding and interpreting the narrations. In addition, the jurisprudential specific rules can vary according to scholars and sects. Though there are the jurisprudential specific rules on which all scholars and sects agree, it is not possible to tell this for all jurisprudential specific rules. And this paves for controversies and different approaches in understanding and evaluating hadiths. It is possible to see the plain example of this in the example of semen as dirt (najis).

Keywords: Hadith, Jurisprudential Specific Rules, Semen, Cleanliness, Sect Imams.

\section{Öz}

\section{Rivayetlerle Fıkhî Zâbıtaların Etkileşimi: Meninin Necaseti Örneği}

Hadis ilmi ile ilgili ihtilaflı meselelerden birisi de rivayetleri sahih veya zayıf kabul etme kriterleriyle ilgilidir. $\mathrm{Bu}$ bağlamda rivayetleri anlama, değerlendirme ve sihhatlerini belirlemede farklı yöntemler kullanıldığı bir hakikattir. Bundan olsa gerektir ki ilk dönemden itibaren hadisleri anlamada ve yorumlamada farklı yaklaşımlar gündeme gelmiştir. Buna bağlı olarak farklı görüş ve mezheplerin ortaya çıkması da kaçınılmaz olmuştur. Öte yandan 
520 | F. ÖZÇELIK / Rivayetlerle Fıkhî Zâbıtaların Etkileşimi: Meninin Necaseti Örneği

kaynağı Kitab, Sünnet ve içtihat olan küllî kâideler ve zâbıtalar, klasik fıkıh edebiyatında müstakil bir tür olarak gelişmiş ve sistemleşmiştir. Bunun yanı sıra âlimlerin, hadisleri anlama ve yorumlamadaki farklı anlayışları neticesinde sahih kabul ettikleri bir rivayetle ilgili farklı sonuçlara ulaştıkları ve bu hususta istinbâtta bulunurken bir takım fıkhi zâbıtalar ortaya koydukları görülmüştür.

$\mathrm{Bu}$ çalışmada meninin necaseti ile ilgili var olan rivayetlerin fıkhî zâbıtalar çerçevesinde ele alınması hedeflenmiştir. Öncelikle temel hadis kaynaklarına müracaat edilerek konuyla ilgili rivayetler tespit edilmiştir. Belirlenen bu rivayetlerin isnad açısından sıhhat durumları izahata kavuşturulmuştur. Akabinde mezhep imamları başta olmak üzere âlimlerin fikhî zâbıtalar bağlamında söz konusu rivayetlerle ilgili yaptığ1 yorumlara değinilmiştir. Bununla beraber rivayetlerin fıkhî zâbitaların üzerindeki etkisine de işaret edilmiştir. Yapılan araştırmanın neticesinde meni ile ilgili birden fazla rivayet tespit edilmiş ve tespit edilen bu rivayetlerin isnad açısından sahih olduğu görülmüştür. Bunun yanı sıra rivayetlerin muhtevasının meninin yıkanması ve çitilenmesi olduğu tespit edilmiştir. Tespit edilebildiği kadarıyla meninin necaseti ile ilgili Hz. Peygamber'in doğrudan bir ifadesi bulunmamaktadır. Hal böyle olunca âlimlerin geliştirdikleri fikhî zâbıtalar çerçevesinde söz konusu rivayetleri yorumladıkları ve bazı istinbatlarda bulundukları görülmüştür.

Hanefilere göre ister yaş ister kuru olsun meni her durumda necistir. Onlar, görüşlerini "Hadese sebep olan her şey haddi zatında necistir." fikhî zâbıtasıyla beraber bazı nakli delillerle temellendirmeye çalışmışlardır. Aynı şekilde Hanefiler meniyi idrar ve hayız kanına kıyas ederek necis olduğunu söylemiştir. Ferk rivayetini kabul eden Hanefilerin, meninin necaseti konusunda fıkhî zâbitayı önceledikleri görülmüştür. Bununla beraber Hanefi mezhebinde "Necis olan bir şeyin yıkanması vaciptir" bilinen bir fıkhî zâbıtadır. Ancak Hanefiler, meni kuru olduğunda bu kaideden istisna etmişler ve çitilemeyi yeterli görmüşlerdir. Böylece rivayet, fıkhî zâbıtaya tercih edilmiştir.

Mâlik b. Enes meniyi necis kabul etmiş ve onun yıkanmasının zorunlu olduğunu iddia etmiştir. Ayrıca Mâlik çitilemeyi yeterli görmemiş ve böyle bir uygulamayı da kabul etmemiştir. Şâfî̂ mezhebinde şöyle bir zâbıta söz konusudur: "Arka ve önden çıkan her sıvı necistir." Buna göre büyük abdest, idrar, kan ve meni necis kabul edilmelidir. Ancak meni bu zâbitadan istisna edilmiş ve temiz olarak kabul edilmiştir. Gerekçe olarak da bazı akli delillerle beraber kıyas ve Hz. Âişe'den nakledilen ferk rivayeti öne sürülmüştür. Yani Şâfiîler rivayeti genel ilkelerine tercih etmişlerdir. 
Ahmed b. Hanbel de meninin temiz olduğunu söylemiştir. Meni için çitilemeyi yeterli görenler, meninin yıkandığını ifade eden rivayetleri sahih kabul etmişlerdir. Onlara göre meninin çitilenmesi necis olduğu için değil tükürük ve toprak gibi mubah şeylerin temizlenmesi gibi temizlik için yapılmıştır. Bu tikel örnekten hareketle rivayetlerin fikhî zâbıtaları etkiledikleri gibi, fıkhî zâbitaların da rivayetleri anlama ve yorumlamada etkili olduğu anlaşılmaktadır. Ayrıca fıkhî zâbıtalar âlimlere ve mezheplere göre değişebilmektedir. Her ne kadar bütün fakîh ve mezheplerin ittifak ettiği fıkhî zâbitalar bulunsa da bütün fıkhî zâbitalar için bunu söylemek mümkün değildir. $\mathrm{Bu}$ da hadisleri anlamada ve değerlendirmede ihtilaflara ve farklı yaklaşımlara zemin hazırlamaktadır. Bunun bariz örneğini meninin necaseti meselesinde görmek mümkündür.

Anahtar Kelimeler: Hadis, Fıkhî Zâbıta, Meni, Temizlik, Mezhep İmamları.

\section{Giriş}

Rivayetleri sahih veya zayıf olarak değerlendirme kriterlerinin, İslam düşünce tarihinde en önemli ve ihtilaflı meselelerden birisi olduğu kabul edilmiştir. Bununla beraber herhangi bir rivayete sahih veya zayıf hükmü verilmesinin ictihadî olduğu ulema tarafından dile getirilmiştir. ${ }^{1}$ Bunun yanı sira hadislerin hem sihhatini tespitte, hem de anlama ve değerlendirmede ihtilafların bulunduğu, bunun da alim ve münekkitlerin yaklaşım ve kriter farklılığından kaynaklandığı görülmüştür. Bundan olsa gerektir ki, ilk dönemden itibaren hadisleri anlama ve yorumlamada farklı yaklaşımlar gündeme gelmiştir. Buna bağlı olarak farklı görüş ve mezheplerin ortaya çıkması da kaçınılmaz olmuştur. $^{2}$

Öte yandan kaynağı Kitab, Sünnet ve içtihat olan küllî kâidelerin, klasik fıkıh edebiyatında müstakil bir tür olarak gelişmesi ve sistemleşmesi h. IV. asra rastlamaktadır. İlk dönemlerde daha önce

1 Zafer Ahmed Tehânevî, Kavâid fì ulûmi'l-hadîs (Beyrut: Dârü'l-Beşâiri'l-İslâmiyye, 2007), 49.

2 Mehmet Özşenel, Hanefi Hadis Anlayışının Teşekkülü (İstanbul: M. Ü İlahiyat Fakültesi Vakfı (IFAV), 2018), 14. 
522 | F. ÖZÇELIK / Rivayetlerle Fıkhî Zâbıtaların Etkileşimi: Meninin Necaseti Örneği

"kâide" 3 yerine asl veya ona yakın anlama gelen zâbıt ve kânûn gibi kelimeler kullanılmıştır. Nitekim zâbıtaların furû-ı fıkıhta da sıklıkla kullanılmaları, onların birer fıkhî kâide olduklarının zannedilmesine yol açmıştır. Bu sebeple kavâid ilminin yaygınlaşması ve tekâmül sürecinin kemal bulmasından sonra literatürde, fıkhî kâideler arasındaki ince ayrıntılardan ötürü, kavâid ile zâbıt ${ }^{4}$ ve usûl kâidelerine yer verilmeye başlanmıştır. ${ }^{5}$

$\mathrm{Bu}$ süreçte âlimlerin hadisleri anlama ve yorumlamadaki farklı anlayışları neticesinde sahih kabul ettikleri bir rivayetle ilgili farklı sonuçlara ulaştıkları ve bu hususta istinbâtta bulunurken bir takım fıkhi zâbıtalar ortaya koydukları görülmektedir. Nitekim meninin necaseti üzerine yapılan tartışmalarında ele aldıkları zâbıtalar konunun önemli örneklerinden biridir. Şöyle ki, furû fıkıhta meninin necaseti, yıkanması ve çitilenmesi gibi konularda mezhepler arasında ihtilaflar zuhur etmiş ve bu konuda rivayetlerin önemli bir faktör olduğu müşahede edilmiştir. Bundan hareketle bu çalışmamızda, hem zâbitaların rivayetlere dair yorumlama ve anlama üzerindeki etkisi hem de rivayetlerin zâbitalarla etkileşimi irdelenecektir.

\section{A. Meniyle İlgili Rivayetlerin Tespiti}

Konuyla ilgili mevcut rivayetleri iki başlık altında toplamak mümkündür. Birincisi meninin yıkanmasını, ikincisi ise çitilemesini ihtiva eden rivayetlerdir.

\section{Yıkamayı İhtiva Eden Rivayetler}

Hadis literatüründe elbiseye bulaşan meninin temizlik amaçlı sadece yıkanmasını ifade eden rivayetler bulunmaktadır. Söz gelimi Buhârî, "Meninin yıkanması, çitilenmesi ve kadından bulaşanın

3 Kâide: “Tüm cüzlerin hükmünü kapsamına alan kesin ve genel önermelerdir." Geniş bilgi için bk. Mehmet Erdoğan, Fıkıh ve Hukuk Terimleri Sözlü̆̆̈̈ (İstanbul: Ensar Neşriyat, 2005), "Kâide", 286.

4 Zâbıt: "Bir mevzuun cüzlerine, kısımlarına uygulanan hükümler. Zâbıta, kîdeden farklıdır. Kâide, çeşitli konulara dair meseleleri, zâbıta ise yalnız bir mevzua ait meseleleri toplar." Geniş bilgi için bk. Erdoğan, Fıkıh ve Hukuk Terimleri Sözlüğü, "Zâbıt", 615.

5 Ahmed Zerkâ, Şerhü'l-kavâ'idi'l-fikhiyye (Dımeşk: Dârü'l-Kalem, 2007), 36. Ayrıca bk. İhsan Akay, "Klasik Fıkıh Literatüründeki Küllı̂ Kâidelerle Mecelle'deki Küllı̂ Kâidelerin Karşılaştırılması", Uluslararası Sosyal Bilimler Kongresi Tam Metin Bildiriler Kitabı, ed. Mehmet Bilen vd. (Diyarbakır: Şarkiyat Bilim ve Hikmet Vakfı Yayını, 2017), 268; Akay, “'Kavâid-i Frkhiyyenin Müstakil Delil Olma Problemi'”, İslâm Hukuku Araştırmaları Dergisi 31 (2018), 91/101. 
yıkanması babı" şeklindeki başlık altında meninin yıkandığını ifade eden rivayetleri tahrîc etmiştir. Buhârî, Abdân $\rightarrow$ Abdullah $\rightarrow$ Amr b. Meymûn $\rightarrow$ Süleyman b. Yesâr isnadiyla tahrîc ettiği rivayete göre $\mathrm{Hz}$. Âişe şöyle demiştir: “Ben Hz. Peygamber'in elbisesindeki meniyi yıkardım, ${ }^{6}$ o da yıkamanın izi olduğu halde namaza giderdi." ${ }^{7}$ Ayrıca Buhârî, muhteva olarak yukarıdaki rivayete benzeyen birden fazla rivayet tahrîc etmiştir. ${ }^{8}$

Buhârî, mezkûr bab başlığı altında "فرك" (çitilenme/ovalama) olarak bilinen rivayeti tahrîc etmemiştir. İbn Hacer'e göre Buhârî'nin adeti üzeri, bab başlığında "فرك" kelimesini kullanarak söz konusu rivayete işarette bulunmuş ve bununla iktifa etmiştir. ${ }^{9}$ Nitekim Buhârî, etTârîhü'l-Kebîr adlı eserinde Rabî' b. Ebî Cehm'in biyografisini verirken ferk rivayetine yer vermiştir. ${ }^{10}$

Müslim, Hz. Âişe'nin, Hz. Peygamber'in elbisesindeki meniyi yıkadığını ifade eden rivayeti, Ebû Bekir b. Ebî Şeybe $\rightarrow$ Muhammed b. Bişr $\rightarrow$ Amr b. Meymûn $\rightarrow$ Süleyman b. Yesâr isnadıyla tahrîc etmiştir. Söz konusu rivayete göre $\mathrm{Hz}$. Âişe şöyle buyurmuştur: “Hz. Peygamber'in menisini yıkardı, sonra aynı elbiseyle namaza giderdi ve ben de onun elbisesindeki yıkama izine bakardım."11 Abdullah $b$. Mübârek'in rivayeti ise Hz. Âişe'nin, “Ben Hz. Peygamber'in elbisesini (meniden) yıkardım." şeklindedir. Müslim söz konusu rivayeti birçok tarikle tahrîc etmiştir. ${ }^{12} \mathrm{~Hz}$. Âişe'nin meniyi yıkadığını ifade eden

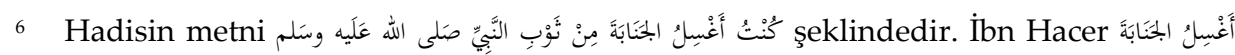
ifadesi ile ilgili şu açıklamayı yapmıştır: "Yani cenabetin eseri, dolayısıyla burada muzaf olan kelime düşmüştür. Veya cünüp ifadesi mecazen meni için kullanmıştır." Bk. Ebü'l-Fazl Şihâbüddîn Ahmed b. Ali b. Muhammed el-Askalânî İbn Hacer, Fethü'l-bârî bi-şerhi Sahîhi'l-Buhârî (Riyâd: Dâru's-Selâm, 2000), 1/434.

7 Ebû Abdillâh Muhammed b. İsmâîl b. İbrâhîm Cu'fî Buhârî, Sahîh (Beyrut: Dâru Tavki'n-Necât, 1422h), "Vudû", 64.

8 Buhârî, "Vudû", 65.

9 İbn Hacer, Fethü'l-bârî bi-şerhi Sahîhi'l-Buhârî, 1/433.

10 Ebû Abdillâh Muhammed b İsmâîl b İbrâhîm Cu'fî Buhârî, et-Târihü'l-kebîr (Beyrut: Dâru'l-Kütübi'l-i̇lmiyye, 2008), 3/241.

11 Ebü'l-Hüseyin el-Kuşeyri en-Nîsâbûrî Müslim b. Haccâc, Sahîh (Kahire : Dâru İhyai'lKütübi'l-Arabiyye, 1955), “Tahâret”, 108.

12 Müslim, “Tahâret", 109-110. 
524 | F. ÖZÇELIK / Rivayetlerle Fıkhî Zâbıtaların Etkileşimi: Meninin Necaseti Örneği rivayet Ebû Dâvud (öl. 275/889), ${ }^{13}$ Tirmizî (öl. 279/892) ${ }^{14}$ ve Nesâî (öl. 303/915) tarafından da tahrîc edilmiştir. ${ }^{15}$

\subsection{Yıkamaya Delalet Eden Rivayetin Kütüb-i Sitte'deki Şeması ve İsnad Açısından Tahlili:}

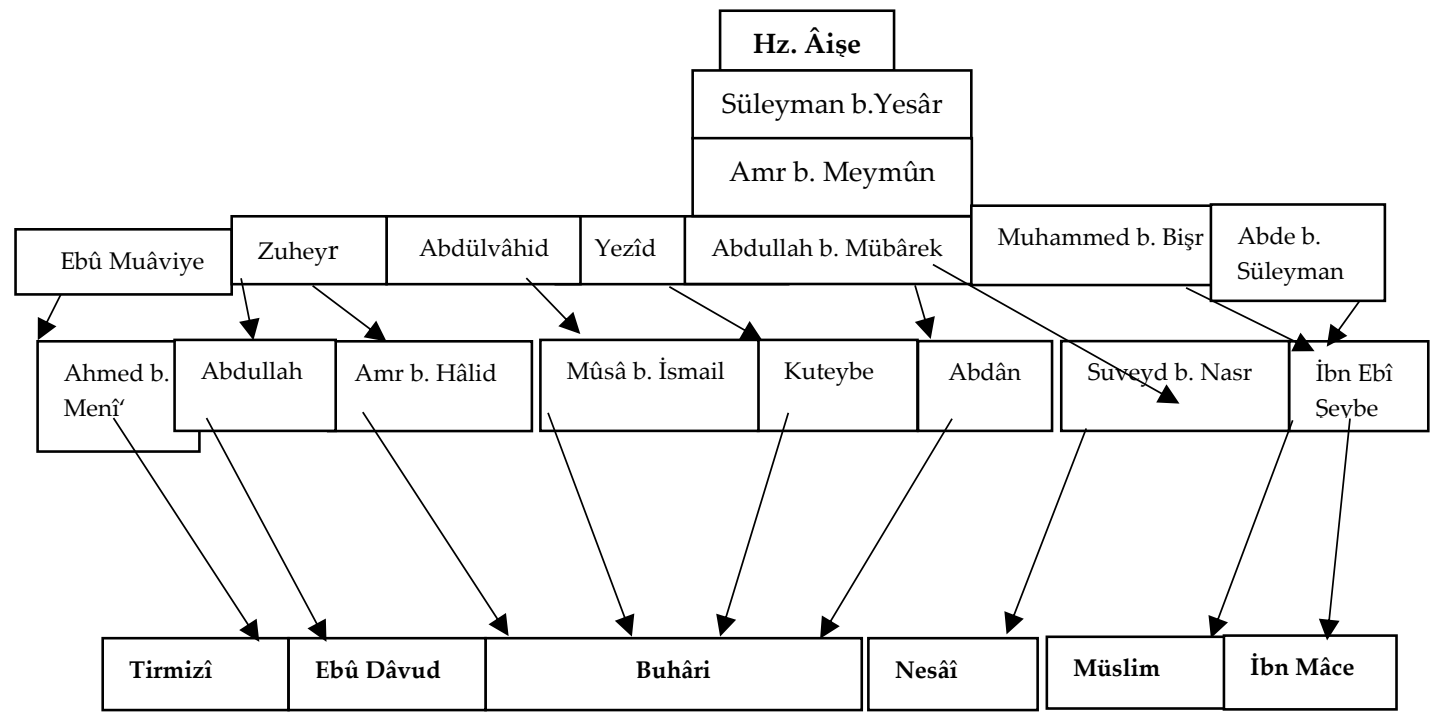

Tespit edebildiğimiz kadarıyla rivayetin sahabi râvisi Hz. Âişe' dir. Ondan da tâbiînden Süleyman b. Yesâr, ondan da Amr b. Meymûn b. Mihrân el-Cezerî rivayet etmiştir. Amr b. Meymûn'dan sonra ise rivayet ağı çoğalmış ve birden fazla râvi tarafından nakledilmiştir. Biz de burada rivayetin medarı olan Süleyman b. Yesâr ve Amr b. Meymûn'un biyografilerini vererek rivayetin sened açısından durumunu tespit etmeye çalışacağız.

Süleyman b. Yesâr (öl. 107/725): Ebû Eyyûb künyesiyle bilinen Süleyman b. Yesar, Hassân b. Sâbit (öl. 60/680), İbn Abbâs (öl. 68/687-88), Ebû Hüreyre (öl. 58/678), İbn Ömer (öl. 73/693) ve Ümmü Seleme (öl. 62/681) gibi sahâbîlerden hadis rivayet etmiştir. Kendisinden de Zührî (öl. 124/742), Amr b. Dînâr (öl. 126/744) ve Katâde (öl. 117/735) başta

13 Süleyman b Eş'as b İshak b el-Ezdi es-Sicistânî Ebû Dâvud, Sünen (Cidde: Darü'lKıble li's-Sekafeti'1-İslamiyye, 1998), “Tahâret", 131.

14 Ebû Îsâ Muhammed b Îsâ Tirmizî, Sünen (Mısır: Mustafa el-Bâbî el-Halebî, 1975), "Tahâret", 86.

15 Ebû Abdirrahman Ahmed b. Ali b. Şuayb Nesâî, Sünen (Haleb: Mektebetü'lMetbûâti'1-İslâmiyye, 1986), “Tahâret”, 187. 
olmak üzere birçok kişi rivayette bulunmuştur. Yahyâ b. Maîn (öl. 233/848) ${ }^{16}$ ve Ebû Zür'a (öl. 264/878) tarafından sika olarak tavsif edilmiştir. $^{17}$ İbn Hibbân'a (öl. 354/965) göre Süleyman b. Yesâr 34/655 yılında doğmuş, 110/729 yılında da vefat etmiştir. Ayrıca İbn Hibbân "Süleyman b. Yesâr Medine'nin fakihlerindendi." diyerek onun ilmi yetkinliğine işarette bulunmuştur. ${ }^{18}$ Zehebî (öl. 748/1348), Süleyman b. Yesâr'ın hadis aldığı kişiler arasında Hz. Âişe'yi (öl. 58/678) de zikretmiştir. Ayrıca Zehebî onu "fakîh, imam, müctehid kadr-1 yüce" olarak tavsif etmiştir. ${ }^{19}$ İbn Mencuye'nin (öl. 428/1036) verdiği bilgilere göre Süleyman b. Yesâr; abdest, salât, fedâil konusunda Hz. Âişe'den rivayette bulunmuştur. ${ }^{20}$

Bezzâr'ın (öl. 292/905), Süleyman b. Yesâr'ın doğrudan Hz. Âişe'den rivayette bulunmadığını ve Süleyman b. Yesâr $\rightarrow \mathrm{Hz}$. Âişe isnadıyla gelen "meninin yıkanması" rivayetinin muallel olduğunu iddia etmiştir. Ancak İbn Hacer (öl. 852/1449) başta olmak üzere hadis münekkitlerine göre Bezzâr'ın bu iddiası makbul değildir. ${ }^{21}$ Nitekim yukarıda geçtiği üzere Buhârî ve Müslim başta olmak üzere hadis âlimlerinin tahrîclerine göre Süleyman b. Yesâr doğrudan Hz. Âişe'den rivayette bulunmuştur. Bunun yanı sıra Buhârî'nin tahrîc ettiği Süleyman b. Yesâr'ın şu ifadesi kendisinin Hz. Âişe ile görüştüğünü net bir şekilde ortaya koymaktadır: “Hz. Âişe'nin huzuruna girmek için izin istedim, sesimi tanıdı ve 'Süleyman! İçeri gir, zira sen memluksün, senin üzerine bir şey kalmamıştır' dedi." ${ }^{22}$ Ayrıca Süleyman b. Yesâr'ın, doğrudan Hz. Âişe' den başka rivayetleri de mevcuttur. ${ }^{23}$

16 Ebû Zekeriyyâ el-Bağdâdî Yahyâ b. Maîn, Târîhu İbn Maîn (Rivâyetü'd-Dûrî) (Mekke: Merkezü'l-Bahsi'l-İlmi ve İhyâi't-Türâsi'l-İslâmî, 1979), 3/157.

17 Ebû Muhammed Abdurrahman b. Muhammed b. İdris Razî İbn Ebî Hatim, el-Cerh ve't-ta'dîl (Beyrut: Dâru İhyâi't-Turâsi'l-Arabî, 1952), 4/149.

18 Ebû Muhammed b. Hibbân b. Ahmed el-Büstî, Kitâbü's-sikât (Haydarabad: Dâiretü'1Maârifi'l-Osmaniyye, 1973), 4/301.

19 Ebû Abdillah Şemseddin Muhammed b Ahmed b Osman Zehebî, Târîhü'l-İslâm ve vefeyâtü̈l-meşâhîr ve'l-a'lâm (Beyrut: Dârü'l-Garbi'l-İslâmî, 2003), 3/57.

20 Ebû Bekr Ahmed b. Ali Muhmamed el-İsfahani İbn Mencûye, Ricâlu Sahîhi Müslim (Beyrut: Dârü'l-Ma'rife, 1987), 1/263.

21 Ebü'l-Fazl Şihâbüddîn Ahmed b. Ali b. Muhammed el-Askalânî İbn Hacer, Telhîsü'lhabîr fî tahrîc-i ehâdîsi'r-Râfiiyyi'l-kebîr (Beyrut: Dârü'l-Kütübi'l-İlmiyye, 1989), 1/175.

22 Buhârî, "Şahâdat", 11.

23 Birkaç örnek için bk. Müslim, "Salât", 889; Ebû Dâvud, “Edeb”, 112. 
526 | F. ÖZÇELIK / Rivayetlerle Fıkhî Zâbıtaların Etkileşimi: Meninin Necaseti Örneği

Diğer taraftan Ricâl ilminde râvilerin doğum ve ölüm tarihleri önemlidir. Bu yolla herhangi bir râvinin kiminle görüşüp görüşmediği tespit edilebilmektedir. Bu hakikatten hareketle Süleyman b. Yesâr'ın doğum tarihi göz önünde bulundurulduğunda kendisinin pekâlâ $\mathrm{Hz}$. Âişe ile görüştüğü ileri sürülebilir. ${ }^{24}$ Süleyman b. Yesâr'ın bazı rivayetleri Urve $\rightarrow \mathrm{Hz}$. Âişe isnadıyla rivayette bulunduğu da bir hakikattir. ${ }^{25}$ Fakat bu rivayetler onun doğrudan $\mathrm{Hz}$. Âişe'den rivayette bulunmadığı anlamına gelmemektedir.

Amr b. Meymûn b. Mihrân el-Cezerî (öl. 145/762): Künyesi Ebû Abdillah olan Amr b. Meymûn; babası, Süleyman b. Yesâr ve Şa'bî (öl. 104/722) başta olmak üzere birçok kişiden hadis rivayet etmiştir. Ondan da Süfyân es-Sevrî (öl. 161/778), Abdullah b. Mübârek (öl. 181/797) Yezîd b. Zürey'(öl. 182/798) ve Yezîd b. Hârûn (öl. 206/821) gibi râviler nakilde bulunmuştur. Ahmed b. Hanbel (öl. 241/855) ondan bir beis olmadı̆̆ını, İbn Maîn ise onun sika olduğunu söylemiştir. ${ }^{26}$ Aynı şekilde İbn Nümeyr (öl. 234/849) ve Nesâî tarafından da sika kabul edilmiştir. ${ }^{27}$ Zehebî, onu imam, hafız ve fakîh olarak tavsif etmiştir. Ayrıca Amr b. Meymûn'un, "Eğer sünnetle ilgili bilmediğim bir harfin Yemen'de olduğunu bilsem onu öğrenmek için onun yanına giderim." dediği nakledilmiştir. Zehebî’ye göre Amr b. Meymûn'un bu sözü onun hadise olan düşkünlüğünü göstermektedir. ${ }^{28}$ Tespit edebildiğimiz kadarıyla Amr b. Meymûn b. Mihrân el-Cezerî hadis münekkitleri tarafından sika kabul edilmiş ve onu tenkit eden herhangi bir münekkit olmamıştır. Zehebî'nin nakline göre Amr b. Meymûn 145/762 tarihinde vefat

24 Yukarıda değinildiği gibi Süleyman b. Yesâr'ın doğumu 34/655'tir. Hz. Âişe'nin vefat tarihi de 58/678 olduğuna göre Süleyman b. Yesâr'ın onunla görüşme imkânı ortaya çıkmaktadır.

25 Birkaç örnek için bk. Ebû Dâvud, "Salât", 262; Ebû Abdullah Muhammed b. Yezid er-Rebei el-Kazvini İbn Mâce, Sünen (Beyrut: Dâru'r-Risâleti'l-Âlemiyye, 2009), “Nikâh”, 34, 1937; Tirmizî, “Radâ'”, 1.

26 İbn Ebî Hatim, el-Cerh ve't-ta'dîl, 6/26; Ebû Abdillâh Şemsüddîn Muhammed b. Ahmed b. Osmân Zehebî, el-Kâşif fî ma'rifeti men lehu rivâye fi'l-kütübi's-sitte (Cidde: Dârü'1-Kible, 1992), 2/89.

27 Ebü'l-Fazl Şihâbüddîn Ahmed b. Ali b. Muhammed el-Askalânî İbn Hacer, Tehzîbü'tTehzîb (Hind: Dâiretü'1-Maârif, 1326), 8/109.

28 Ebû Abdillah Şemseddin Muhammed b Ahmed b Osman Zehebî, Siyeru a'lâmi'nnübelâ (Beyrut: Müessesetü'r-Risâle, 1985), 6/346. 
etmiştir. $^{29} \mathrm{Bu}$ açıklamalar bağlamında Hz. Âişe'nin meniyi yıkadı̆̆ını ifade eden rivayetlerin isnad açısından sahih olduğu görülmektedir.

\section{2. Çitilemeyi İhtiva Eden Rivayetler}

"فرك/Ferk" hadisi olarak meşhur olan rivayet birçok hadis kaynağında yer almaktadır. Daha önce değinildiği üzere Buhârî bab başlığında "فركـ/ferk" ifadesine değinmekle yetinmiştir. Fakat Müslim başta olmak üzere birçok muhaddis ferk rivayetini tahrîc etmiştir. Söz gelimi Müslim "باب حكم المني/Meninin hükmünün babı" şeklindeki başlık altında birden fazla rivayete yer vermiştir. Rivayetlerden birisi Ömer b. Hafs (öl. 154/771) $\rightarrow$ Hafs b. Giyâs (öl. 194/810) $\rightarrow$ A'meş (öl. 148/765) $\rightarrow$ İbrahim en-Nehaî (öl. 96/714) $\rightarrow$ Esved (öl. 75/694) ve Hemmâm isnadıyla gelmiştir. Rivayete göre Hz. Âişe şöyle demiştir: "Ben Hz. Peygamber'in elbisesini çitilerdim." ${ }^{30}$ Müslim'den (öl. 261/875) tahrîc edilen diğer bir rivayet de Yahyâ b. Yahyâ (öl. 226/840-841) $\rightarrow$ Hâlid b. Abdillah (öl. 182/798) $\rightarrow$ Hâlid (öl. ?) $\rightarrow$ Ebû Ma'şer (öl. 120/737) $\rightarrow$ İbrahim $\rightarrow$ Alkame ve Esved isnadıyla gelmiştir. Rivayette geçtiği üzere bir adam Hz. Âişe'nin misafiri oldu, sabah olduğunda adam elbisesini yıkamaya başladı. Bunun üzerine Hz. Âişe şöyle buyurdu: “Eğer bir şey görüyorsan, onun yerini yıkaman yeterlidir. Şayet bir şeyi bulamıyorsan etrafını sıkman kâfidir. Ben Hz. Peygamber'in elbisesini çitiliyordum, o da o elbiseyle namaz kılard1." ${ }^{31}$ Ayrıca Müslim, söz konusu rivayeti birden fazla tarikle tahrîc etmiştir. ${ }^{32}$ Müslim'in tahrîc ettiği bir rivayete göre ise Hz. Âişe'nin misafiri olan kişi Abdullah b. Şihâb elHavlânı̂'dir. ${ }^{33}$

İbn Mâce (öl. 273/887) ${ }^{34}$ ve Ebû Dâvud (öl. 275/889) da hem ferk rivayetini hem de $\mathrm{Hz}$. Âişe'ye misafir olan kişinin hikayesini içeren rivayeti tahrîc etmişlerdir. ${ }^{35}$ Nesâî (öl. 303/915) ise meseleyi " فرك المني من الثوب/Elbisedeki meniyi çitilenme babı" olarak belirlemiş ve bu başlik altında birden fazla rivayete yer vermiştir. Nesâî́nin tahrîc ettiği

\footnotetext{
29 Zehebî, el-Kâşif fî ma'rifeti men lehu rivâye fi'l-kütübi's-sitte, 2/89.

30 Müslim, "Tahâret", 288.

31 Müslim, "Tahâret", 288.

32 Müslim, "Tahâret", 107.

33 Müslim, "Tahâret", 290.

34 İbn Mâce, "Tahâret", 82.

35 Ebû Dâvud, "Tahâret", 131.
} 
528 । F. ÖZÇELIK / Rivayetlerle Fıkhî Zâbıtaların Etkileşimi: Meninin Necaseti Örneği

rivayetler muhteva olarak Müslim'in naklettiği ferk rivayetiyle hemen hemen aynidır. ${ }^{36}$

Tespit edebildiğimiz kadarıyla Tirmizî (öl. 279/892), Hz. Âişe'ye misafir olan kişinin durumunu ihtiva eden rivayeti tahrîc etmiştir. ${ }^{37}$ Tirmizî rivayetin akabinde meni için çitilemenin yeterli geleceğini söyleyen birçok sahabi olduğunu, aynı şeklide Süfyân, Ahmed, İshâk gibi fakîhler de bu görüşte olduğunu söylemiştir. Ayrıca Tirmizî Hz. Ầişe'nin meniyi yıkadığını ifade eden rivayeti tahrîc ettikten sonra şu açıklamayı yapmıştır: “Hz. Âişe'nin Hz. Peygamber'in elbisesindeki meniyi yıkadığını ifade eden rivayet, ferk rivayetine muhalif değildir. Zira ferk her ne kadar yeterli olsa da kişinin, elbisesindeki meninin eserini görmemesi müstahaptır." Tirmizî daha sonra Abdullah b. Abbâs'1n "Meni tükürük gibidir, onu izhir (yaprak) ile sil" sözünü tahrîc etmiştir. ${ }^{38}$

Ahmed b. Hanbel ferk rivayetini Muhammed b. Ebî Adî $\rightarrow$ Saîd b. Ebî Arûbe (öl. 156/773) $\rightarrow$ Ebû Ma'şer (Ziyâd b. Kuleyb) $\rightarrow$ İbrahim enNehaî $\rightarrow$ Esved b. Yezîd en-Nehaî isnadıyla tahrîc etmiştir. Rivayete göre Hz. Âişe şöyle buyurmuştur: “Ben meniyi Hz. Peygamber'in elbisesinde çitilerdim. Onu görüyorsan yıka, eğer görmüyorsan su serp." ${ }^{39}$ Ebû Ya'lâ el-Mevsılî de (öl. 307/919) söz konusu rivayeti Ebû Musâ'nın ziyadesiyle aynı isnad ve aynı lafızlarla rivayet etmiştir. ${ }^{40}$ İshâk b. Râhûye (öl. 238/853) rivayeti Abde b. Süleyman $\rightarrow$ Saîd b. Ebî Arûbe $\rightarrow$ Ebû Ma'şer $\rightarrow$ İbrahim en-Nehaî $\rightarrow$ Esved b. Yezîd en-Nehaî isnadıyla rivayet etmiştir. İshâk b. Râhûye rivayetin akabinde şu açıklamayı yapmıştır: "Yaş iken yıkardı, kuru olduğunda ise çitilerdi." ${ }^{41}$ İbnü'l-Cârûd (öl. 307/919-20) ise rivayeti Muhammed b. Yahyâ $\rightarrow$ Muhammed b. Adbullah el-Ensârî $\rightarrow$ Hişâm b. Hassân $\rightarrow$ Ebû Ma'şer $\rightarrow$ İbrahim en-Nehaî $\rightarrow$ Esved b. Yezîd en-Nehaî isnadıyla Hz. Âişe'nin şöyle dediğini nakletmiştir: “Ben meniyi Hz. Peygamber'in elbisesinden

36 Nesâî, "Tahâret", 192.

37 Tirmizî, "Tahâret", 85.

38 Tirmizî, "Tahâret", 86.

39 Ebû Abdullah Ahmed b Muhammed eş-Şeybani Ahmed b. Hanbel, Müsned (Beyrut: Müessesetü'r-Risâle, 2001), 40/74.

40 Ahmed b Ali b el-Müsenna Ebû Ya'la el-Mevsıli, Müsnedu Ebî Ya'la el-Mevsılî (Cidde: Dârü'l-Me'mun li't-Türas, 1989), 8/265.

${ }^{41}$ Ebû Ya'kub İshak b İbrâhim b Mahled İshak b. Râhûye, Müsnedu İshak b. Râhûye (Medîne: Mektebü'l-Îmân, 1991), 3/834. 
F. ÖZÇELIK / Transaction of Jurisprudential (Fiqhî) Specific Rules with Narrations: Example of Semen as Dirt I 529 çitilerdim, akabinde Hz. Peygamber namaz kılardı." Hadisin râvisinden olan Muhammed el-Ensârî̀ye "kastın cünüblük mü?" şeklinde sorulması üzerine Muhammed el-Ensârî, "Başka ne olabilir ki." şeklinde cevap vermiştir. ${ }^{42}$

\section{1. Çitilemeye Delalet Eden Rivayetlerin Kütüb-i Sitte'deki Şeması ve İsnad Açısından Tahlili:}

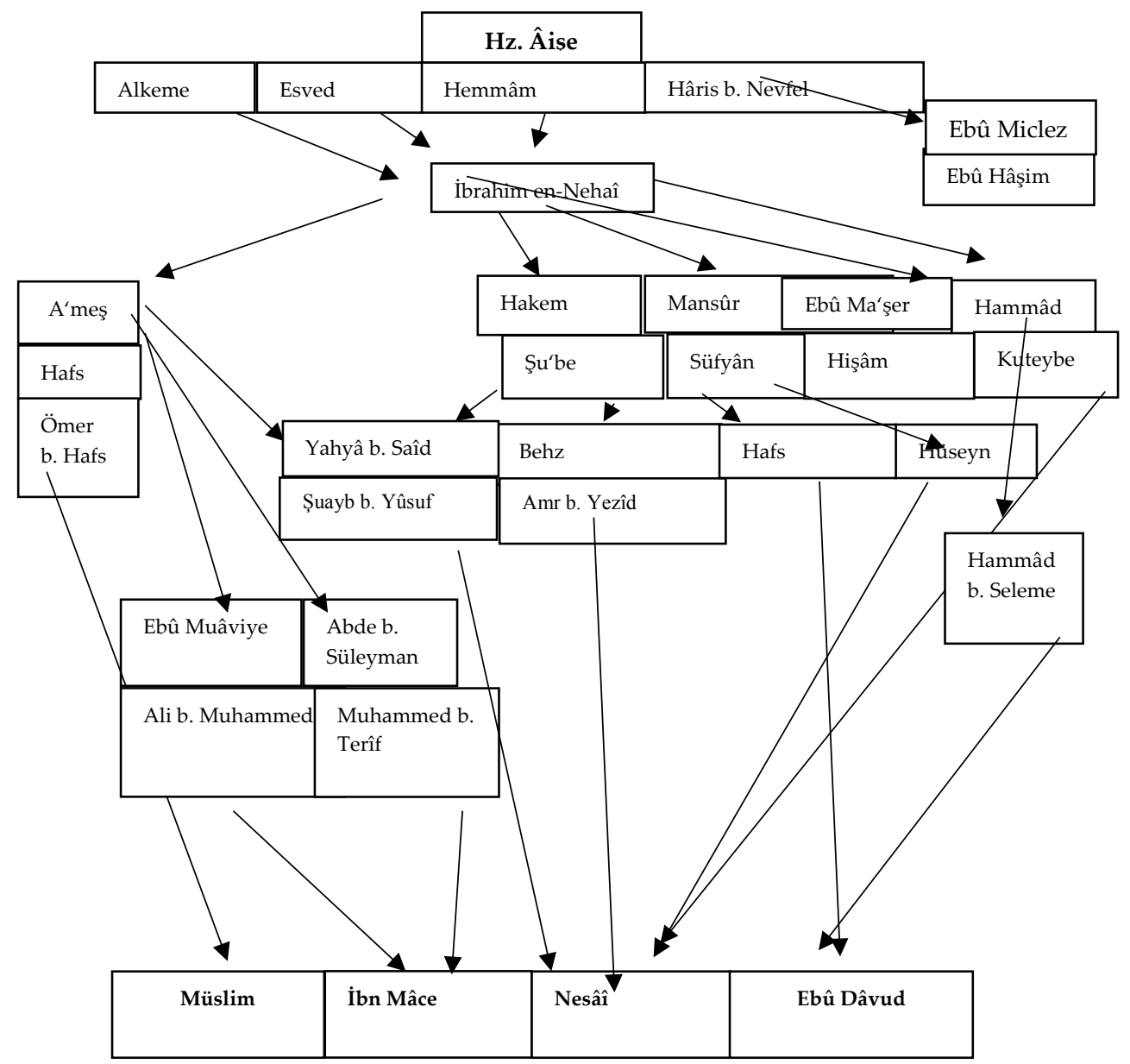

Şemada da görüldüğü gibi çitilemeye delalet eden rivayetlerin sahabi râvisi Hz. Âişe' dir. Ondan da Hâris b. Nevfel, Hemmâm b. Hâris,

42 Ebû Muhammed Abdullah b. Ali b el-Cârûd İbnü'l-Cârûd, el-Müntekâ mine's-süneni'lmüsnedi an Resulillâh (Beyrut: Kitâbü's-Sakâfiyye, 1988), 44. 
530 | F. ÖZÇELIK / Rivayetlerle Fıkhî Zâbıtaların Etkileşimi: Meninin Necaseti Örneği

Alkame ve Esved en-Nehaî rivayet etmiştir. Bunlardan da İbrahim enNehaî ve Ebû Miclez nakletmiştir. Rivayetlerin bundan sonraki tariki çoğalmış ve birçok kişi tarafından rivayet edilmiştir. Biz de burada rivayetlerin medarı olan râvilerin biyografilerini özet bir şekilde sunacağız. Ancak Hâris b. Nevfel sahabi olduğu için adalet açısından tenkit dişı tutulmuştur. ${ }^{43}$

Alkame b. Kays (öl. 62/682): Muhadramûndan ${ }^{44}$ olan Alkame b. Kays, ilim için Kûfe'ye yerleşmiş ve Abdullah b. Mes'ûd'un (öl. 32/65253) has öğrencisi olarak kabul edilmiştir. Alkame Hz. Ömer (öl. 23/644), Hz. Osman (öl. 35/656), Hz. Ali (öl. 40/661) ve Hz. Âişe başta olmak üzere birçok sahâbiden rivayette bulunmuştur. Kendisinden de Ebû Vâil (öl. 82/701), Şa'bî, İbrahim en-Nehaî ve Muhammed b. Sîrîn (öl. 110/729) gibi âlimler hadis nakletmiştir. ${ }^{45}$ Alkame Kûfe'nin fakîhi olmakla beraber âlim, hafız, büyük müctehid gibi vasıflarla tavsif edilmiştir. ${ }^{46}$ Alkame Yahyâ b. Maîn ve Ahmed b. Hanbel gibi hadis münekkitleri tarafından sika kabul edilmiştir. ${ }^{47}$

Hemmâm b. Hâris en-Nehaî (öl. 63/682): Hemmâm b. Hâris Hz. Ömer, oğlu Abdullah, Ebû Mes’ûd el-Ensârî, Ebû Derdâ (öl. 32/652?), Hz. Âişe ve Cerîr b. Abdillah gibi sahâbîlerden hadis rivayet etmiştir. ${ }^{48}$ Kendisinden de İbrahim en-Nehaî, Süleyman b. Yesâr ve Vabara b. Abdirrahman (öl. 116/735) gibi râviler nakilde bulunmuştur. ${ }^{49}$ İbn Sa'd'ın (öl. 230/845), Hemmâm’ın Kûfe'de Haccâc'ın valiliği döneminde

43 Bilindiği sahâbîler adalet açısından tenkit dışı tutulmuştur. Hâris b. Nevfel Hz. Peygamber, Hz. Ebû Bekir, Hz. Ömer ve Hz. Osman döneminde kendisine bazı görevler verilmiştir (bk. Ebû Abdillah Muhammed İbn Sa'd, et-Tabakâtü'l-kübrâ (Beyrut: Dârü'l-Kütübi'l-İlmiyye, 1990), 4/41.) Ancak Hâris b. Nevfel'in, pek de hadis rivayetinde bulunmadığ görülmektedir. Zehebî'nin tespitine göre Hâris, sadece ferk rivayetini Hz. Âişe'den nakletmiştir (bk. Zehebî, Tarihü'l-İslâm ve vefeyatü'l-meşahir ve'l-a'lâm, 2/255.)

44 Muhadramûnun tanımı için bk. Mehmet Efendioğlu, "Muhadramûn", Türkiye Diyanet Vakfi İslâm Ansiklopedisi (İstanbul: TDV Yayınları, 2005), 30/395-396.

45 Ebû Abdillah Muhammed İbn Sa'd, et-Tabakâtü'l-kübrâ (Beyrut: Dârü'1-Kütübi'1İlmiyye, 1990), 6/146; Zehebî, Siyeru a'lâmi'n-nübelâ, 4/54.

46 Zehebî, Siyeru a'lâmi'n-nübelâ, 4/53.

47 İbn Ebî Hatim, el-Cerh ve't-ta'dîl, 6/404.

48 İbn Sa'd, et-Tabakâtü'l-kübrâ, 6/172.

49 Ebü'l-Haccâc Cemâleddin Yusuf b Abdurrahman b Yusuf Mizzî, Tehzîbü'l-Kemâl fî esmâi'r-ricâl (Beyrut: Müessesetü'r-Risâle, 1980), 30/297. 
F. ÖZÇELIK / Transaction of Jurisprudential (Fiqhî) Specific Rules with Narrations: Example of Semen as Dirt I 531 vefat ettiğini söylemiştir. ${ }^{50}$ İbn Hibbân ise Hemmâm'ın Yezîd b. Muâviye döneminde 64/684 yılında vefat ettiğini nakletmiştir. ${ }^{51}$ Hemmâm hadis münekkitleri tarafından sika olarak kabul edilmiştir. ${ }^{52}$

Esved b. Yezîd en-Nehaî (öl. 75/694): Ebû Amr ve Ebû Abdirrahman künyeleriyle de bilinen Esved b. Yezîd. Hz. Ebû Bekir, Hz. Ömer, Hz. Âişe, Hz. Ali ve Muaz b. Cebel (öl. 17/638) başta olmak birçok sahabiden hadis rivayet etmiştir. Kendisinden de İbrahim en-Nehaî ve yeğeni olan İbrahim b. Yezîd en-Nehaî, Ebû Fâhite (90/708) ve Eş'as b. Ebî Şa'sa' (öl. 125/742) gibi birçok kişi rivayette bulunmuştur. Esved b. Yezîd Yahyâ b. Maîn ve Ahmed b. Hanbel başta olmak üzere hadis münekkitleri tarafından sika kabul edilmiştir. ${ }^{53}$

İbrahim en-Nehaî (öl. 96/714): Künyesi Ebû İmrân olan İbrâhîm b. Yezîd b. Esved en-Nehaî el-Kûfî nisbesiyle bilinmektedir. Nehaî, dayısı Esved b. Yezîd, Mesrûk ve Alkame b. Kays başta olmak üzere birçok tâbiînden hadis rivayet etmiştir. Kendisinden de Mansûr, A‘meş, Muğîre ve Hammâd b. Ebî Süleyman başta olmak üzere birçok kişi rivayette bulunmuştur. ${ }^{54}$

Nehaî'nin tâbiînden olduğu kabul edilmekle birlikte sahâbeden hadis nakletmesi meselesi ulema arasında tartışılmıştır. ${ }^{55}$ Nehaî'nin, çocuk iken Hz. Âişe'nin huzuruna girdiğine dair nakil Yahyâ b. Maîn ve Ebû Hâtim tarafından rivayet edilmiştir. ${ }^{56}$ İbn Sa'd'a göre ise İbrahim Hz. Âişe'nin huzuruna girmiş, Zeyd b. Erkam, Muğîre b. Şu'be ve Enes b. Mâlik'ten hadis işitmiştir. ${ }^{57}$

Ali b. Medînî, Nehaî'nin hiçbir sahâbe ile görüşmediğini iddia etmiştir. Hz. Âişe ile görüştüğüne dair var olan rivayet kendisine sorulduğunda, "Bu rivayet sadece Saîd b. Ebî Arûbe $\rightarrow$ Abû Ma'şer $\rightarrow$

50 İbn Sa'd, et-Tabakâtü'l-kübrâ, 6/173.

51 İbn Hibbân, Kitâbü's-sikât, 5/510.

52 Ebü'l-Hasan Ahmed b. Abdullah b. Salih İclî, Ma'rifetü's-sikât (Medine: Mektebetü'dDâr, 1985), 461; İbn Ebî Hatim, el-Cerh ve't-ta'dîl, 9/107; İbn Hacer, Tehzîbü't-Tehzîb, $11 / 66$.

53 Mizzî, Tehzîbü'l-Kemâl fî̀ esmâi'r-ricâl, 3/233.

54 İbn Ebî Hatim, el-Cerh ve't-ta'dîl, 2/144; Zehebî, Siyeru a'lâmi'n-nübelâ, 4/520.

55 Şükrü Özen, "Nehaî", Türkiye Diyanet Vakfı İslâm Ansiklopedisi (İstanbul: TDV Yayınları, 2006), 32/535.

56 Yahyâ b. Maîn, Târîhu İbn Maîn (Rivâyetü'd-Dûrî), 3/485; İbn Ebî Hatim, el-Cerh ve'tta'dîl, 2/144.

57 Zehebî, Siyeru a'lâmi'n-nübelâ, 4/524. 
532 | F. ÖZÇELIK / Rivayetlerle Fıkhî Zâbıtaların Etkileşimi: Meninin Necaseti Örneği

İbrahim isnadıyla gelmiş; Saîd b. Ebî Arûbe ise zayıftır" demiştir. ${ }^{58}$ Bunun yanı sıra Nehaî'nin Ebû Cühyfe, Zeyd b. Erkam, İbn Ebî Evfa'yı gördüğü ancak bunlardan hadis işitmediği nakledilmiştir. Ebû Hâtim ise Nehâ̂'nin hiçbir sahâbîyle görüşmediğini, ancak çocuk iken $\mathrm{Hz}$. Âişe'nin huzuruna girdiğini, Hz. Ömer'den olan rivayetlerin ise mürsel olduğunu söylemiştir. Ebû Zür'a da Nehaî'nin Hz. Ömer, Hz. Ali ve Sa'd b. Ebî Vakkâs'tan olan rivayetleri mürsel olarak kabul etmiştir. ${ }^{59}$ Aynı şeklide Zehebî de Nehaî'nin hiçbir sahâbîden hadis işitmediği, bununla beraber Ebû Dâvûd, Nesâî ve İbn Mâce'nin Nehaî $\rightarrow \mathrm{Hz}$. Âişe isnadıyla rivayet ettiği bazı hadisleri tahrîc etmişse de bu rivayetler muttasıl kabul edilmemektedir. Zira hadis münekkitlerine göre Nehaî büyük tâbiînden sayılmamaktadır. ${ }^{60}$

Bütün bu değerlendirmeler çerçevesinde Nehaî'nin, tabiînden olmasına rağmen hiçbir sahâbîden hadis işitmediği görüşü daha makbuldür, diye düşünüyoruz. Bununla beraber Irak'ta ehl-i re'y mektebinin ortaya çıkmasında merkezî bir rol oynayan Nehaî, ${ }^{61}$ hadis münekkitleri başta olmak üzere birçok kişi tarafından fakîh, âlim, imam ve hafız gibi vasıflarla nitelenmiştir. ${ }^{62}$ Şemada da görüldüğü gibi meninin çitilemesini ifade eden rivayetlerin medarı İbrahim enNehaî'dir.

Ebû Miclez Lâhık b. Humeyd es-Sedûsî (öl. 110/728): Ebû Miclez künyesiyle de bilinen Lâhık b. Humeyd, Abdullah b. Ömer, Abdullah b. Abbâs ve Enes b. Mâlik gibi sahâbîlerden hadis rivayet etmiştir. Ondan da Katâde ve Süleyman et-Teymî başta olmak üzere birçok kişi rivayette bulunmuştur. ${ }^{63}$ Tedlîs yaptığına dair görüşler bulunsa da İbn Sa'd, Ebû Zür'a ve Zehebî gibi âlimler tarafından sika kabul edilmiştir. ${ }^{64}$ İbn

58 Ebû Zür'a Veliyyüddîn Ahmed b. Abdirrahîm b. el-Hüseyn el-Kürdî el-Mihrânî İbnü'l-Irâkî, Tuhfetü't-tahsîl fî̀ zikri ruvâti'l-merâsîl (Riyad: Mektebetü'r-Rüşd, 1999), 19.

59 İbnü'l-Irâkî, Tuhfetü't-tahsîl fî zikri ruvâti'l-merâsîl, 20.

60 Zehebî, Siyeru a'lâmi'n-nübelâ, 4/520-521.

61 Özen, “Nehầ”, 32/32, 537.

62 Zehebî, Siyeru a'lâmi'n-nübelâ, 4/520.

63 Buhârî, et-Târihü'l-kebîr, 8/258.

64 İbn Sa'd, et-Tabakâtü'l-kübrâ, 7/162; Ebû Abdillah Şemseddin Muhammed b Ahmed b Osman Zehebî, Mîzânü'l-i'tidâl fî̀ nakdi'r-ricâl (Beyrut: Dârü'l-Ma'rife, 1963), 4/356. 
F. ÖZÇELIK / Transaction of Jurisprudential (Fiqhî) Specific Rules with Narrations: Example of Semen as Dirt I 533

Hibbân'a göre Ebû Miclez Kûfe'de Hasan-1 Basrî̀den kısa bir müddet önce vefat etmiştir. ${ }^{65}$

Yukarıdaki bilgiler bağlamında ferk rivayetinin isnadında yer alan râviler genel olarak güvenilir kabul edilmiştir. Dolayısıyla konuyla ilgili rivayetlerin isnad açısından sahih olduğu görülmektedir.

\section{B. Fıkhî Zâbıtalar Bağlamında Rivayetlerin Tahlili}

Fıkhî mezheplerin istikrarından sonra ortaya çıkan fıkhî kâidelerin, İslâm hukukunun dayandığı ana ilkeleri, gözettiği amaçları ihtiva ettiği fıkhî meselelere pratik çözümler ürettiği ve fıkıh tefekkürünün olgunlaşmasına katkı sağladığı malumdur. ${ }^{66}$

Bununla beraber rivayetlerin fikıh kuralları üzerindeki etkisi veya fıkıh kurallarının rivayetleri yorumlamadaki tesirinin üzerinde durulması gereken bir husus olduğu kanaatindeyiz. Bu hakikatten hareketle aşağıda meninin necaseti örneğinde rivayetlerin fikhî zâbıtalara etkisinin izah edilmesi hedeflenmektedir.

Konun detaylarına geçmeden önce hemen ifade edilmelidir ki meninin necaseti ile ilgili bazı farklı detaylar bulunmakla beraber netice olarak, bir görüşe göre meni necis iken diğer bir görüşe göre temiz olduğu hakkında iki görüşün öne çıktığı görülmektedir. Şimdi bu iki görüşü delilleriyle beraber izah etmeye çalışacağız.

\section{1- Meninin Necis Olduğunu Söyleyen Görüş}

Hanefî âlimleri, meniyi necis kabul ederek islak olduğunda yıkanmasını zorunlu, elbise üzerinde kurursa ovmayı/çitilemeyi yeterli görmüşlerdir. ${ }^{67}$ Hanefiler, meninin necis olduğu şeklindeki görüşlerini rivayetlerle temellendirmeye çalışmışlardır. Söz gelimi Hz. Âişe'nin Hz.

65 Ebû Hâtim Muhammed b. Hibbân b. Ahmed el-Büstîi İbn Hibbân, Meşâhîru ulemâi'lemsâr (Kahire : Dârü'l-Kütübi'l-İlmiyye, 1959), 91.

66 İhsan Akay, "Klasik Fikıh Literatüründeki Küllî Kâidelerle Mecelle'deki Küllî Kâidelerin Karşılaştırılması", Uluslararası Sosyal Bilimler Kongresi Tam Metin Bildiriler Kitabı, ed. Mehmet Bilen vd. (Diyarbakır: Şarkiyat Bilim ve Hikmet Vakfı Yayını, 2017), 267.

${ }^{67}$ Ebû Bekr Ahmed b. Alî er-Râzî Cessâs, Şerhu Muhtasari't-Tahâvî fi'l-fikhi'l-Hanefî (Beyrut: Dârü'l-Beşâiri'l-İslâmiyye, 2010), 2/58; Ebû Bekr Şemsüleimme Muhammed b Ahmed b. Sehl Serahsî, el-Mebsût (Beyrut: Dâru'l-Fikr, 2000), 1/144; Ebü'l-Fazl Mecdüddîn Abdullāh b. Mahmûd b. Mevdûd Mevsılî, el-İhtiyâr li-ta'lîli'l-Muhtâr (Beyrut: Dâru'l-Erkam, 1418), 1/50; Ebû'l-Hasen Burhânüddîn Alî b. Ebî Bekr b. Abdilcelîl el-Fergânî el-Mergînânî, el-Hidâye şerhu Bidâyeti'l-mübtedî (Beyrut: Dâru'lErkam, 1999), 1/43. 
534 | F. ÖZÇELIK / Rivayetlerle Fıkhî Zâbıtaların Etkileşimi: Meninin Necaseti Örneği

Peygamber'in elbisesindeki meniyi yaş iken yıkadığını ifade eden rivayetler bu bağlamda değerlendirilmiştir. Meninin necasetine hükmedenlerin delil getirdiği bir başka nakil de Hz. Peygamber'in Ammâr b. Yâsır'a söylediği şu rivayettir: "Elbise ancak beş şey sebebiyle yıkanır; İdrar, büyük abdest, içki, kan ve meni." ${ }^{68}$ Bunun yanı sıra Abdulah b. Mübarek $\rightarrow$ Ma'mer $\rightarrow$ Zührî $\rightarrow$ Talha b. Abdillah isnadiyla gelen rivayete göre Ebû Hüreyre meni ile ilgili şöyle demiştir: "Eğer onu görüyorsan yıka, eğer görmüyorsan elbisenin tamamını yıka." Tahâvî (öl. 321/933) bu rivayetten hareketle Ebû Hüreyre'nin, meniyi necis kabul ettiğini söylemiştir. ${ }^{69}$

Hanefî âlimleri, ayrıca meninin necasetini kıyas ve akli delillerle açıklamaya çalışmışlardır. Söz gelimi Tahâvî konuyla ilgili: "Bu ihtilaflar söz konusu olduğunda ve Hz. Peygamber'den naklettiğimiz rivayetlerden meninin hükmüne delâlet eden bir naklinin olmamasından dolayı istinbât yöntemine itibar ettik. Bunun yanı sıra meninin zuhurunu büyük abdestlik (cünüplük) sebebi olarak gördük, zira meni büyük tahareti gerektirmektedir. Bu sebeple biz de hadesi gerektiren şeylerin hükmünü araştırmak istedik. Bu bağlamda büyük abdest ve idrarın necis olmakla beraber hadese yol açtıklarını gördük. Aynı şekilde hayız ve istihaze kanı da necis kabul edilmekte ve hadese sebep olmaktadır. Damarların kanı da böyledir. Zikrettiğimiz bilgilere göre, hadese yol açan her şeyin haddi zatında da necis olduğu sabit olmuştur. Meninin de hadese sebep olduğu tespit edildiğinde, meninin haddi zatında necis olması da kesinlik kazanmıştır. Meninin hükmüne ilişkin kıyas bu şekildedir" diyerek konu hakkında görüşlerini serdetmiştir. $^{70}$ Keza Serahsî (öl. 483/1090?) de naklî delillere istinaden meniyi hayız kanına kıyas ederek necis olduğunu söylemiştir. ${ }^{71}$

Bu bilgiler 1şı̆̆ında iki temel ilkeden/zâbıtadan söz etmek mümkündür: Birincisi "Hadese sebep olan her şey haddi zatında

68 Serahsî, el-Mebsût, 1/145. Dârekutnî'nin, söz konusu rivayet sadece Sâbit b. Hammâd tarafından rivayet edildiğini, Sâbit ve isnadda yer İbrahim'in zayıf olduğunu söylemiştir. Geniş bilgi için bk. Ebü'l-Hasan Ali b Ömer b Ahmed Dârekutnî, elİlelü'l-varide fi'l-ehâdîsi'n-nebeviyye (Beyrut: Müessesetü'r-Rayyân, 2011), 1/230.

69 Ebû Ca'fer Ahmed b Muhammed b Selâme b Abdülmelik b Seleme Ezdî Hacrî Misrî Tahâvî, Şerhu meân'̂l'-âsâr (Riyâd: Âlemü'l-Kütüb, 1994), 1/52.

70 Tahâvî, Şerhu meân'̂l-âsâr, 1/53.

71 Serahsî, el-Mebsût, 1/145. 
F. ÖZÇELIK / Transaction of Jurisprudential (Fiqhî) Specific Rules with Narrations: Example of Semen as Dirt I 535 necistir." İkinicisi ise "Necis olan bir şeyin yıkanması vaciptir."72 Bununla beraber âlimler, büyük abdest, idrar, hayız ve istihaze kanının hadese sebep olduğu konusunda ittifak etmişlerdir. Diğer bir ifadeyle kişinin bedeninde bahsi geçen hallerden biri ortaya çıktığında o kişinin ya abdest ya da gusül alması gerekmektedir. ${ }^{73}$ Aynı şeklide hadese sebep olan büyük abdest, idrar, hayı ve istihaze kanının necaseti konusunda ittifak söz konusudur. ${ }^{74}$ Tahâvî bu ilkelerden hareketle insanın damarlarından çıkan kanın, hadese (abdestliğe) sebep olduğu için necis olduğunu söylemiştir. ${ }^{75}$

Yukarıda değinildiği gibi necasetin yıkanmasına ilişkin; "Necis olan bir şeyin yıkanması vaciptir" bir zâbıta benimsenmiştir.76 Hanefî mezhebine göre idrar gibi sıvı necasetinin elbiseye bulaştı̆̆ında muhakkak yıkanması gerekmektedir. Buna göre meniyi necis kabul eden Hanefîlere göre, diğer necasetler gibi o da her durumda yıkanmalıdır. Ancak Hanefîler, meninin kuru halini yukarıda geçen zâbıtadan istisna etmiş ve onunla ilgili çitilemekle yetinmişlerdir. ${ }^{77}$

Hanefilerin, meninin kuru iken çitilenmesini yeterli görmelerinin nedeni Hz. Âişe'den nakledilen rivayettir. Nitekim Tahâvî ${ }^{78}$ ve Serahsî başta olmak üzere Hanefî âlimleri meni ile ilgili çitileme hükmünü şu rivayete dayandırmışlardır: "Peygamber'in Hz. Âişe'ye yönelik "onu (meniyi) yaş gördüğünde yıka, kuru gördüğünde ise çitile” buyruğuna binaen Hz. Âişe'nin "Ben Hz. Peygamber'in elbisesindeki meniyi çitilerdim, Hz. Peygamber de (o elbiseyle) namaz kılardı."

Görüldüğ̈̈ üzere bu konunun dayanak noktası, haber-i vâhid ve kıyastır. Şu var ki haber-i vâhidin, kıyasa karşı durumu ulema arasında tartışılmıştır. Ancak bu ve bunun gibi örnekler de gösteriyor ki, Hanefî mezhebinde haber-i vâhidin kıyasa tercih edilmesi önceliklidir. Nitekim

72 Tahâvî, Şerhu meânî'l-âsâr, 1/53; Serahsî, el-Mebsût, 1/145.

73 Mergînânî, el-Hidâye şerhu Bidâyeti'l-mübtedî, 1/17; Abdülganî b. Tâlib el-Guneymî elMeydânî, el-Lübâb fî şerhi'l-Kitâb (Beyrut: Dâru İhyâi't-Turâsi'l-Arabî, 1998), 1/11; Muhammed b. Ahmed el-Hatîb Şirbînî, Muğgn̂̀l-Muhtâc (Beyrut: Dâru'l-Kütübi'lİlmiyye, 1994), 1/139.

74 Bk. Mevsilî, el-ïhtiyâr li-ta'lîli'l-Muhtâr, 1/48-49; Şirbînî, Muğnî'l-Muhtâc, 1/71-80.

75 Tahâvî, Şerhu meânî'l-âsâr, 1/53.

76 Tahâvî, Şerhu meânî'l-âsâr, 1/53; Serahsî, el-Mebsût, 1/145.

77 Mergînânî, el-Hidâye şerhu Bidâyeti'l-mübtedî, 1/43; Mevsılî, el-İhtiyâr li-ta'lîli'l-Muhtâr, $1 / 50$.

78 Tahâvî, Şerhu meânî̀l-âsâr, 1/53. 
536 | F. ÖZÇELIK / Rivayetlerle Fıkhî Zâbıtaların Etkileşimi: Meninin Necaseti Örneği

Debûsî'nin (öl. 430/1039) şu ifadeleri bunun apaçık delilidir: “Üç imama göre (Ebû Hanîfe, Ebû Yusuf, Muhammed) asıl olan, Hz. Peygamber'den âhâd tarikle nakledilen haberin, sahih kıyasa takdim edilmesidir. Ancak Mâlik'e göre sahih kıyas, âhâd habere mukaddemdir. Ashabımız bu asla istinaden "meni necistir, kuru olduğunda elbise çitilenmekle temiz olur demişlerdir. Mâlik ise idrar gibi meni ancak yıkamakla temiz olur söylemiştir." ${ }^{\prime 79}$ Debûsî devamında Hanefîlerin haber-i vâhidi kıyasa tercih etme sadedinde birçok meseleyi örnek olarak sunmuştur. ${ }^{80}$ Bunun yanı sıra Hanefilerin haber-i vâhidi kıyasa öncelediğine dair başka örnekleri de bulmak mümkündür. Dolayısıyla Hanefîler, meninin kuru iken çitilenmekle yetinilmesi rivayetini kıyasa tercih etmişlerdir. ${ }^{81}$ Ancak Hanefîler her ne kadar çitilemeyi yeterli görmüşlerse de meninin kuru olduğunda da necis olduğunu kabul etmişlerdir. ${ }^{82}$ Bunun yanı sıra bazı Hanefî âlimler, meninin idrara göre insanın elbisesine bulaşma ihtimali çok olduğu için çitilenme eylemini yeterli görmüştür. ${ }^{83}$ Dolayısıyla çitilemekle yetinilmesi meninin temiz olduğundan değil, insanlara kolaylık olsun diye böyle bir hüküm verilmiştir.

Hanefîlerin, Hz. Âişe'nin "meninin çitilemesi" rivayeti karşısında iki farklı tutumları söz konusudur. Başka bir ifadeyle Hanefîler bir yönüyle bu rivayetle amel etmiş, bir yönüyle de rivayete muhalefet etmişlerdir. Daha önce değinildiği gibi Hanefîlerin benimsediği temel kurala göre hadese sebep olan her şey haddi zatında necistir veya insanın bedeninden çıkan her necis şey hadese sebep olmaktadır. Ayrıca şöyle genel bir kural da söz konusudur: "Necis olan bir şeyin yıkanması

79 Ebû Zeyd Abdullāh (Ubeydullāh) b. Muhammed b. Ömer b. Îsâ Debûsî, Te'sisü'nnazar (Beyrut: Dâru İbn Zeydûn, ts.), 99-100.

80 Debûsî, Te'sisü'n-nazar, 100.

81 İsmail Hakkı Ünal, İmam Ebu Hanife'nin Hadis Anlayışı ve Hanefi Mezhebinin Hadis Metodu (Ankara: Diyanet İşleri Başkanlığı, 2010), 179. Hanefîlerin rivayeti kıyasa tercih ettiği bazı meseleler için bk. Hüseyin Kahraman, "Hadislere Göre Cinsel Organa Dokunmanın (Messü'l-Ferc) Abdeste Etkisi", Uludă̆ Üniversitesi İlahiyat Fakültesi Dergisi 19/1 (01 Ocak 2010), 111-142; Hüseyin Kahraman, “Namazda Kahkaha ile Gülmenin Abdeste Etkisi", Uludă̆ Üniversitesi İlahiyat Fakültesi Dergisi 19/2 (01 Haziran 2010), 73-92.

82 Cessâs, Şerhu Muhtasari't-Tahâvî fi'l-fikhi'l-Hanefî, 2/60.

83 Mevsilî, el-İhtiyâr li-ta'lîli'l-Muhtâr, 1/49; Mergînânî, el-Hidâye şerhu Bidâyeti'l-mübtedî, $1 / 43$. 
vaciptir. Guslün vücubiyeti ancak necis şeyler için söz konusudur". ${ }^{84}$ Ancak Hanefîler, meninin kuru iken bulaştı̆̆ vacip olmadığını kabul ederek hadisin zahiriyle amel etmişlerdir. Yani rivayeti, temel ilke/zâbitaya mukaddem kılmışlardır. Fakat Hanefîlerin meniyi necis kabul etmeleri, zâbitayı rivayete tercih etmeleri anlamına gelir. Zira Hanefîler, “فرك المني" rivayetini sahih kabul etmekte, ancak "Hadese sebep olan her şey haddi zatında necistir" genel kuralından hareketle her ne kadar, kuru meninin çitilenmesi ile elbise temiz oluyorsa da meni, haddi zatında necistir. Böylece Hanefîler "Meni necistir" demekle hadisin lazımı ile amel etmeyi terk etmiş, ilkeleriyle amel etmişlerdir. Zira "فرك "rivayetinin zahiri değil, lazımı meninin necis olmadığını göstermektedir. Zira Hz. Âişe'nin çitileme ile iktifa etmesi, meninin necis olmadı̆̆ını lazım kılmaktadır. Buna karşın Hanefîlerin "Meninin kuru iken yıkanması vacip değildir" demeleri de "ferk" rivayetini "Necis olan bir şeyin yıkanması vaciptir" ilkesine tercih etmektir. Nitekim Tahâvî "Ancak şu kadar var ki biz, onun kuru olduğu zaman mubah olmasının hükmünü araştırdığımızda bu konuda Hz. Peygamber'den nakledilen rivayet olduğunu gördük. Bu (kuru iken mubah olması), Ebû Hanîfe (öl. 150/767), Ebû Yûsuf (öl. 182/798) ve Muhammed'in (öl. 189/805) görüşüdür." ${ }^{85}$ diyerek bu gerçeğe işaret etmiştir. Buradaki mubahtan kasıt, elbisenin temiz olmasıdır, yoksa meninin bizzat temiz olduğu değildir. Zira Hanefîlere göre meni her durumda necistir. ${ }^{86}$

Buna göre Hanefîler meninin hükmü ile ilgili her iki temel ilkeye göre de amel etmişlerdir denilebilir. Yani bir yönüyle rivayet temel ilkeye/zâbitaya tercih edilmiş, bir yönüyle de temel ilke/zâbita hadisin lazımina tercih edilmiştir.

Hanefî âlimlerinin bazı yorumlarının mezhebin görüşünü savunma saikiyle yapıldı̆̆ı söylenebilir. Söz gelimi Tahâvî́nin Hz. Âişe'nin ferk rivayetini Hz. Peygamber'in gece elbisesi için söz konusu olduğu yaklaşımı bu bağlamda değerlendirilebilir. ${ }^{87}$ Aynı şekilde Abdullah b. Abbâs'ın meniyi izhir denilen yaprakla temizlediğine dair

84 Ebû Abdullah Muhammed b. Ali b. Muhammed el-Havlânî Şevkânî, Neylü'l-evtâr şerhu Münteka'l-ahbâr (Beyrut: Dârü'l-Kütübi'l-i̇lmiyye, 2011), 1/65.

85 Tahâvî, Şerhu meânî'l-âsâr, 1/53.

86 Cessâs, Şerhu Muhtasari't-Tahâvî fi'l-fikhi'l-Hanefî, 2/60.

87 Tahâvî, Şerhu meânî'l-âsâr, 1/50. 
538 | F. ÖZÇELIK / Rivayetlerle Fıkhî Zâbıtaların Etkileşimi: Meninin Necaseti Örneği rivayet varid olmuştur. ${ }^{88}$ Serahsî'nin söz konusu rivayeti, "İbn Abbâs, meniyi hüküm açısından değil, görüntü olarak tükürüğe benzetmiştir." ${ }^{89}$ şeklindeki şerhi de bu kapsamda değerlendirilebilir.

Mâlik b. Enes (öl. 179/795) meniyi necis kabul etmiş ve onun yıkanmasını zorunlu olarak telakki etmiştir. Nitekim kendisi “îhtilam sebebiyle elbisenin yıkanması vacip olup nezdimizde üzerinde icma edilmiştir." demiştir. Mâlik ve arkadaşlarına göre meni ve diğer necasetlerin yıkanması gerekmektedir. Ayrıca Mâlik çitilemeyi yeterli görmemiş ve böyle bir uygulamayı da kabul etmemiştir. ${ }^{90}$ İmam Mâlik'in bazı öğrencileri ise çitileme rivayetini "su ile ovalamak" şeklinde yorumlamışlardır. Ancak onların bu iddiası da zayıftır. Zira yukarıda Müslim'in bir rivayetinde geçtiği üzere $\mathrm{Hz}$. Âişe'nin "tırnaklarımla çitilerdim" ifadesi bulunmaktadır. ${ }^{91}$ Bununla beraber Mâliki mezhebine göre meni, ya haddi zatında veya idrarın yerinde geçtiği için necis olduğu şeklindeki mesele ihtilaflıdır. ${ }^{92}$

\section{2- Meninin Necis Olmadığını Söyleyenlerin Görüşü}

Şâfiî mezhebinde şöyle bir zâbita söz konudur: "Arkadan ve önden çıkan her sıvı necistir." ${ }^{\prime 93}$ Buna göre büyük abdest, idrar, kan ve meni necis kabul edilmelidir. Ancak meni bu genel kuraldan istisna edilmiş ve temiz olarak kabul edilmiştir. ${ }^{94}$ Meniyi temiz kabul edenler, görüşlerini hem nakli hem de akli delillerle temellendirmeye çalışmışlardır. Söz gelimi İmam Şâfiî̀’ye (öl. 204/820) göre Allah, Âdem'i su ve topraktan yaratmış ve her iki maddeyi de temiz kılmıştır. Böylece Allah'ın ilk yaratması temiz maddeden olduğu için daha sonraki mahlûkatları da necis bir şeyden yaratması mümkün değildir. İmam Şâfiî daha sonra bu düşüncesini Hz. Âişe'nin “Ben Hz. Peygamber'in

88 Tahâvî, Şerhu meânî'l-âsâr, 1/52.

89 Serahsî, el-Mebsût, 1/145.

90 Ebû Ömer Cemâlüddîn Yûsuf b. Abdillâh b. Muhammed b. Abdilber en-Nemerî İbn Abdilber, el-İstizkâr (Beyrut: Dârü'l-Kütübi'l-İlmiyye, 2000), 1/287.

91 İbn Hacer, Fethü'l-bârî bi-şerhi Sahîhi'l-Buhârî, 1/433.

92 Ebü'l-Abbâs Şihâbüddîn Ahmed b. İdrîs b. Abdirrahmân el-Misrî Karâfî, ez-Zahîre (Beyrut: Dârü'l-Garbi'l-İslâmî, 1994), 1/186; Tâcüddîn Ebû'l-Bekâ Behrâm b. Abdillah b. Abdülaziz ed-Demîrî Dimyâtî, eş-Şâmil fî fikhi'l-İmam Mâlik (Dublin: Merkezu Necibeveyh li'l-Mahtutat ve Hidmeti't-Türas, 2008), 1/49.

93 Şihâbüddîn Ahmed b. Hüseyn Ebû Şuca', el-Gâyetü ve't-Takrîb (Beyrut: Âlemü'lKütüb, ts.), 6; Ebû Hafs Siraceddin Ömer b. Ali b. Ahmed İbnü'l-Mülakkin, et-Tezkira fîl'-fikhi'ş-Şâfî̀ (Beyrut: Darü'l-Kütübi'l-i̇lmiyye, 2006), 18.

94 Şirbînî, Mŭğnî'l-Muhtâc, 1/234. 
elbisesindeki meniyi çitilerdim." rivayetiyle temellendirmiştir. Ayrıca İmam Şâfî̀’ye göre meninin çitilenmesi necis olduğundan değil, tükürük ve toprak gibi mubah şeylerin temizlenmesi gibi, temizlik amaçlı yapılmıştır. ${ }^{95}$ İmam Şâfiî̀'nin bu görüşü mezhebin önde gelen âlimleri tarafından da dile getirilmiş ve kabul görmüştür. ${ }^{96}$

Görüldüğ̈̈ gibi meniyi temiz kabul edenlerin dayandı̆̆ı deliller kıyas ve rivayetlere dayanır. Dolayısıyla Şafiiler de kıyasa başvurmuşlardır. Bu görüşü savunanların başvurduğu rivayetlerin başında Hz. Âişe'den nakledilen rivayet ile Abdullah b. Abbâs'in "Meniyi izhir ile sil, zira o tükürük gibidir." rivayeti gelmektedir. ${ }^{97}$ Ancak Mâverdî’nin tahrîc ettiği rivayete göre Hz. Âişe şöyle demiştir: "Hz. Peygamber namazdayken onun elbisesindeki meniyi çitilerdim." Mâverdî bu rivayetin, meniyi necis kabul eden Ebû Hanîfe ve Mâlik'in aleyhinde olduğunu söylemiştir. ${ }^{98}$ Ancak tespit edebildiğimiz kadarıyla Hz. Âişe'nin bu ifadesi temel hadis kitaplarında yer almayıp sadece Mâverdî tarafından tahrîc edilmiştir. Nitekim Nevevî de rivayetin bu lafızlarla nakledilmesini garip görmüştür. ${ }^{99}$ Bununla beraber Beyhakî, söz konusu rivayeti naklettikten sonra şöyle demiştir: "Her ne kadar Muhârib b. Disâr ile Hz. Âişe arasında irsal olsa da önceki rivayetler bunu desteklemektedir." ${ }^{100}$ Hal böyleyken Mâverdî’nin naklettiği rivayetin zayıf olduğu söylenebilir.

Meninin yıkanmasını ifade eden rivayetler ile فرك/çitilemenin yer aldığı rivayetler arasında bir teâruz olduğu düşünülebilir. Ancak İbn Hacer'e göre her iki rivayet arasında bir teâruz söz konusu değildir. Ona göre "yıkama" ifadesi vücuba değil, müstahaba delalet etmektedir. Bu yaklaşım İmam Şâfîi, Ahmed b. Hanbel ve ehl-i hadis tarafından da

95 Ebû Abdillâh Muhammed b. İdrîs b. Abbâs Şâfiî, Kitâbü'l-Üm (Beyrut: Darü'lKütübi'l-İlmiyye, 1990), 8/72.

96 Ebû İbrâhim İsmail b. Yahyâ b. İsmail eş-Şafii Müzenî, Muhtasarü'l-Müzen̂̂ fî füru'i'şŞâfiìyye (Beyrut: Dârü'l-Kütübi'l-İlmiyye, 1998), 31; Ebü'l-Hasen Alî b. Muhammed b. Habîb el-Basrî Mâverdî, el-Hâvi'l-kebîr fî fikhi mezhebi'l-İmâmi'ş-Şâfî̀ (Beyrut: Dârü'lKütübi'l-İlmiyye, 1999), 2/251; Ebû Zekeriyyâ Yahyâ b. Şeref b. Mürî Nevevî, elMecmû' şerhi'l-Mühezzeb (Beyrut: Dârü'1-Fikr, ts.), 2/553.

97 Mâverdî, el-Hâvi'l-kebîr fí fikhi mezhebi'l-İmâmi'ş-Şâfî̀, 2/251.

98 Mâverdî, el-Hâvi'l-kebîr fi fikhi mezhebi'l-İmâmi'ş-Şâfiî, 2/252.

99 Nevevî, el-Mecmû' şerhi'l-Mühezzeb, 2/553.

100 Ebû Bekr Ahmed b el-Hüseyin b Ali Beyhakî, Ma'rifetü's-sünen ve'l-asar (Karaçi: Câmiatü'd-Dirasati'l-İslâmiyye, 1991), 3/383. 
540 । F. ÖZÇELIK / Rivayetlerle Fıkhî Zâbıtaların Etkileşimi: Meninin Necaseti Örneği

benimsenmiştir. Dolayısıyla bu âlimlere göre meni ister yaş olsun ister kuru olsun necis değildir. Ayrıca İbn Hacer'e göre meninin necisliğine hükmeden âlimlere göre de bu rivayetler arasında herhangi bir çelişki söz konusu değildir. Buna göre yıkanmanın geçtiği rivayetler, meninin yaş; çitilemenin yer aldığ 1 rivayetler ise menin kuru olduğu zamana hamledilecektir. Ancak İbn Hacer meninin necis olmadığını savunanların görüşünü tercih etmektedir. Zira bu durumda her iki çeşit rivayetle de amel edilmektedir. Ayrıca eğer meni necis olsaydı çitilemekle yetinmeyecekti. Söz gelimi necis kabul edilen kan ve diğer necislerde sadece çitileme kabul edilmemektedir. Ayrıca meni için sadece çitilemenin geçtiği rivayetler de vardır. Bu rivayetler de meninin necis olmadı̆̆ını göstermektedir. ${ }^{101}$

Bazı âlimler Hz. Âişe' nin meniyi necis kabul ettiğini iddia etmiş ve delil olarak da İbn Ebî Dâvud $\rightarrow$ Müseddid $\rightarrow$ Yahyâ b. Saîd $\rightarrow$ Şu'be $\rightarrow$ Abdurrahman b. Kâsım $\rightarrow$ babası Kâsım isnadıyla gelen rivayete göre Hz. Âişe, meninin bulaştı̆̆ı elbise ile ilgili şöyle buyurmuştur: "Meniyi gördüğünde yıka, eğer onu görmüyorsan su serp." ${ }^{102}$ Tahâvî, söz konusu rivayeti birden fazla isnadla tahrîc etmiştir. Bu rivayetten hareketle meninin Hz. Âişe'nin nezdinde necis olduğu düşünülebilir. Ancak bu görüş de tenkide açıktır. Şöyle ki, eğer Hz. Âişe meniyi idrar ve kan başta olmak üzere diğer necis maddeleri gibi kabul etseydi meninin isabet edip yeri belli olmayan elbisenin tamamının yıkanması gerekecektir. Ancak Hz. Âişe'nin, meninin fark edilmediğinde elbiseye su serpmekle iktifa etmesi, meninin hükmünün diğer necisler gibi olmadığını göstermektedir. Tahâvî bu itirazı zikretmiş, ancak herhangi bir cevap vermemiştir. ${ }^{103}$

İbn Hibbân, Âişe'nin (r.a.) Hz. Peygamber'in elbisesindeki meniyi yıkadığını ifade eden rivayetin akabinde şöyle demiştir: "Âişe (ra) Hz. Peygamber' in elbisesindeki meniyi yaş olduğunda yıkardı, zira meninin yıkanması nefse hoş gelmektedir. Meni kuru olduğunda ise çitilerdi ve Hz. Peygamber o elbiseyle namaz kılard1. Biz böyle diyor ve bunu tercih ediyoruz: 'Meninin yaş iken yıkanması necis olduğu için değil, nefse hoş geldiği içindir. Aynı şeklide meni kuru olduğunda çitilemek ile

\footnotetext{
101 İbn Hacer, Fethü'l-bârî bi-şerhi Sahîhi'l-Buhârî, 1/433.

102 Tahâvî, Şerhu meânî'l-âsâr, 1/51.

103 Tahâvî, Şerhu meânî'l-âsâr, 1/51.
} 
F. ÖZÇELIK / Transaction of Jurisprudential (Fiqhî) Specific Rules with Narrations: Example of Semen as Dirt I 541 yetinmek sünnette uymak içindir." ${ }^{104}$ Dolayısıyla meninin temiz olduğunu söyleyenler, söz konusu rivayetlere itiraz etmediklerini, yıkamanın müstahab olduğunu söylemişlerdir. ${ }^{105}$

Konuyla ilgili Ahmed b. Hanbel'den iki farklı görüş nakledilmiştir. Ancak kendisinin de meniyi temiz kabul ettiği yaklaşım mezhepte daha makbul ve meşhur olmuştur. ${ }^{106}$

Sahâbilerin, meninin hükmü ile ilgili ihtilaf ettiği görülmüştür. Söz gelimi Sa'd b. Ebî Vakkâs'ın, meninin bulaştığı elbisesini çitilediği rivayet edilmiştir. ${ }^{107}$ Aynı şekilde Hz. Ömer'in de elbisesinde gördüğü meniyi yıkadığını, görmediği kısma ise su serptiği nakledilmiştir. ${ }^{108}$ Yukarıda geçtiği üzere Ebû Hüreyre meniyi necis kabul etmiştir. Abdullah b. Abbâs ise "İzhir (çubuk) ile silin" diyerek onu tahir olarak kabul ettiğini göstermektedir. ${ }^{109}$ Abdullah b. Ömer ise meni ile ilgili “ نضح fiilini "su serpmek" şeklinde yorumlamıştır. ${ }^{111}$ Ancak Tahâvî نض fiilinin "yıkamak" anlamına da gelebileceğini söylemiştir. ${ }^{112}$ Konuyla ilgili Câbir b. Semure'den şöyle bir nakil rivayet edilmiştir: "(Meninin bulaştığı elbise ile) namaz kıl, ancak eğer bir şey görüyorsan yıka, su serpme, zira su serpmek ancak kötülüğü (kirlenmeyi) çoğaltır." Aynı şekilde Enes b. Mâlik'e elbiseye bulaşıp yeri belli olmayan meninin hükmü sorulması üzerine "Onu yıka" diyerek cevap vermiştir. ${ }^{113}$ Ayrıca tâbiîlerden Saîd b. Müseyyeb (öl. 94/713) ve Atâ b. Ebî Rebâh'ın (öl. 114/732) meniyi temiz kabul ettikleri nakledilmiştir. ${ }^{114}$

104 Ebû Hâtim Muhammed b. Hibban b. Ahmed et-Temîmî İbn Hibbân, Sahîhu İbn Hibbân (Beyrut: Müessesetü'r-Risâle, 1993), 4/220.

105 Nevevî, el-Mecmû' şerhi'l-Mühezzeb, 2/554.

106 Ebû Muhammed Muvaffakuddîn Abdullah b Ahmed b Muhammed b Kudâme Cemmâîlî Makdisî İbn İbn Kudâme, el-Mugnî (Riyâd: Âlemü'l-Kütüb, 1997), 2/497.

107 Tahâvî, Şerhu meânî'l-âsâr, 1/52.

108 Tahâvî, Şerhu meân $\hat{\imath}^{\prime}$-âsâr, 1/52.

109 Tahâvî, Şerhu meânî̀l-âsâr, 1, 52.

110 Tahâvî, Şerhu meân'̂l-âsâr, 1/53.

111 Ebü's-Seâdât Mecdüddîn el-Mübârek b. Esîrüddîn Muhammed b. Muhammed eşŞeybânî el-Cezerî İbnü'l-Esîr, en-Nihâye fî̀ garîbi'l-hadîs ve'l-eser (Beyrut: Dâru'lMa'rife, 2006), 2/754.

112 Tahâvî, Şerhu meânî'l-âsâr, 1/53.

113 Tahâvî, Şerhu meânî'l-âsâr, 1/53.

114 Mâverdî, el-Hâvi'l-kebîr fî fikhi mezhebi'l-İmâmi'ş-Şâfî̀, 2/251. 
542 | F. ÖZÇELIK / Rivayetlerle Fıkhî Zâbıtaların Etkileşimi: Meninin Necaseti Örneği

\section{Sonuç}

Kur'ân ve Sünnet ışığında, fikhî kaideler başta olmak üzere birçok kavâid ve zâbıta ortaya çıkmıştır. Gelişen bu kaideler zaman içerisinde nasları yorumlamada etkili olmuştur. Nitekim bu çalışmada ele alınan meninin necaseti ile ilgili ihtilaflar bunun apaçık delilidir.

Meni ile ilgili birden fazla rivayet tespit edilmiştir. Söz konusu rivayetlerin isnad açısından sahih olduğu görülmüştür. Bunun yanı sıra İmam Mâlik'in dışındaki hadis münekkitleri ve mezhep imamları meni ile ilgili nakledilen rivayetleri sahih kabul etmişlerdir. Ayrıca söz konusu rivayetlerde meninin yıkanması ve çitilenmesi ön plana çıkmıştır. Söz gelimi bazı rivayetlerde Hz. Âişe'nin, Hz. Peygamber'in elbisesine bulaşan meniyi yıkadığı ifade edilmiştir. Bazı rivayetlerde ise sadece çitilemekle iktifa edildiği görülmüştür. Âlimler genel olarak meninin yıkanmasını yaş, çitilenmesini ise kuru olma haline yorumlamışlardir.

Tespit edilebildiği kadarıla meninin necaseti ile ilgili $\mathrm{Hz}$. Peygamber'in doğrudan bir ifadesi bulunmamaktadır. Ancak konu üzerinde mezhep imamları ihtilaf etmişlerdir. Hanefilere göre ister yaş ister kuru olsun meni her durumda necistir. Onlar, görüşlerini "Hadese sebep olan her şey haddi zatında necistir" fıkhî zâbıtasıyla beraber bazı nakli delillerle de temellendirmeye çalışmışlardır. Söz gelimi $\mathrm{Hz}$. Âişe'nin Hz. Peygamber'in elbisesindeki meniyi yaş iken yıkadığını ifade eden rivayetler bu bağlamda değerlendirilmiştir. Aynı şekilde Hanefiler meniyi idrar ve hayız kanına kıyas ederek necis olduğunu söylemiştir. Ferk rivayetini kabul eden Hanefilerin, meninin necaseti konusunda fıkhî zâbıtayı önceledikleri görülmektedir.

Bununla beraber Hanefi mezhebince "Necis olan bir şeyin yıkanması vaciptir" ifadesi bilinen bir fıkhî zâbıtadır. Buna göre necis olan meni kan ve idrar başta olmak üzere diğer necasetler gibi her durumda yıkanmalıdır. Ancak Hanefiler, meni kuru olduğunda bu kaideden istisna etmişler ve çitilemeyi yeterli görmüşlerdir. Hanefi mezhebine mensup âlimler bu görüşlerini Hz. Âişe'nin ferk rivayetine dayandırmışlardır. Dolayısıyla meni kuru olduğunda çitilemekle yetinilmesinden anlaşıldığı kadarıyla rivayet fıkhî zâbıtaya tercih edilmiştir.

Mâlik b. Enes meniyi necis kabul etmiş ve yıkanmasının zorunlu olduğunu iddia etmiştir. Ayrıca Mâlik çitilemeyi yeterli görmemiş ve böyle bir uygulamayı da kabul etmemiştir. 
Şâfiî mezhebinde şöyle bir zâbita söz konudur: "Arka ve önden çıkan her sıvı necistir." Buna göre büyük abdest, idrar, kan ve meni necis kabul edilmelidir. Ancak meni bu zâbıtadan istisna edilmiş ve temiz olarak kabul edilmiştir. Gerekçe olarak da bazı akli delillerle beraber kıyas ve Hz. Âişe'den nakledilen ferk rivayeti öne sürülmüştür. Yani Şâfiîler rivayeti genel ilkelere tercih etmişlerdir. Ahmed b. Hanbel de meninin temiz olduğunu söylemiştir.

Meni için çitilemeyi yeterli görenler, meninin yıkandığını ifade eden rivayetleri sahih kabul etmişlerdir. Onlara göre meninin çitilenmesi necis olduğu için değil, tükürük ve toprak gibi mubah şeylerin temizlenmesi gibi temizlik için yapılmıştır. Bu tikel örnekten hareketle rivayetlerin fıkhî zâbıtaları etkiledikleri gibi, fıkhî zâbıtaların da rivayetleri anlama ve yorumlamada etkili olduğu anlaşılmaktadır. Ayrıca fıkhi zabıtalar, âlimlere ve mezheplere göre değişebilmektedir. Her ne kadar bütün fakîh ve mezheplerin ittifak ettiği fikhî zâbıtalar bulunsa da bütün fıkhî zâbıtalar için bunu söylemek mümkün değildir. Her âlim ve mezheb tarafından tespit edilen ve dikkate alınan zâbıtalar da mevcuttur. Bu da hadisleri anlama ve değerlendirmede ihtilaflara ve farklı yaklaşımlara zemin hazırlamaktadır. Bunun bariz örneğini meninin necaseti meselesinde görmek mümkündür.

\section{Kaynakça}

Ahmed b. Hanbel, Ebû Abdullah Ahmed b. Muhammed eş-Şeybânî. Müsned. 45 Cilt. Beyrut: Müessesetü'r-Risâle, 2001.

Akay, İhsan. "Klasik Fıkıh Literatüründeki Küllî Kâidelerle Mecelle'deki

Küllî Kâidelerin Karşılaştırılması". Uluslararası Sosyal Bilimler

Kongresi Tam Metin Bildiriler Kitabı. ed. Mehmet Bilen vd.. 319-323.

Diyarbakır: Şarkiyat Bilim ve Hikmet Vakfı Yayını, 2017.

Akay, İhsan. "'Kavâid-i Fikhiyyenin Müstakil Delil Olma Problemi'”. İslâm Hukuku Araştırmaları Dergisi 31 (2018), 91-101.

Beyhakî, Ebû Bekr Ahmed b. el-Hüseyin b. Ali. Ma'rifetü's-sünen ve'lasar. 10 Cilt. Karaçi: Câmiatü'd-Dirâsâti'l-İslâmiyye, 1991.

Buhârî, Ebû Abdillâh Muhammed b. İsmâîl b. İbrâhîm Cu'fî. et-Târihü'lkebîr. 9 Cilt. Beyrut: Dâru'l-Kütübi'l-İlmiyye, 2008.

Buhârî, Ebû Abdillâh Muhammed b. İsmâill b. İbrâhîm Cu'fî. Sahîh. 9 Cilt. Beyrut: Dâru Tavki'n-Necât, 1422h. 
544 | F. ÖZÇELIK / Rivayetlerle Fıkhî Zâbıtaların Etkileşimi: Meninin Necaseti Örneği

Cessâs, Ebû Bekr Ahmed b. Alî er-Râzî. Şerhu Muhtasari't-Tahâvî fi'lfikhi'l-Hanefî. 8 Cilt. Beyrut: Dârü'l-Beşâiri'l-İslâmiyye, 2010.

Dârekutnî, Ebü'l-Hasan Ali b. Ömer b. Ahmed. el-Illelü'l-vâride fi'lehâdîsi'n-nebeviyye. 10 Cilt. Beyrut: Müessesetü'r-Rayyân, 2011.

Debûsî, Ebû Zeyd Abdullāh (Ubeydullāh) b. Muhammed b. Ömer b. Îsâ. Te'sisü'n-nazar. Beyrut: Dâru İbn Zeydûn, ts.

Dimyâtî, Tâcüddîn Ebû'l-Bekâ Behrâm b. Abdillah b. Abdülaziz edDemîrî. eş-Şâmil fî fikhi'l-İmâm Mâlik. 2 Cilt. Dublin: Merkezu Necibeveyh li'l-Mahtûtât ve Hıdmeti't-Türas, 2008.

Ebû Dâvud, Süleyman b. Eş’as b İshak b. el-Ezdi es-Sicistânî. Sünen. 4 Cilt. Cidde: Darü'l-Kible li's-Sekafeti'l-İslamiyye, 1998.

Ebû Şuca', Şihâbüddîn Ahmed b. Hüseyn. el-Gâyetü ve't-Takrîb. Beyrut: Âlemü'l-Kütüb, ts.

Efendioğlu, Mehmet. “Muhadramûn”. Türkiye Diyanet Vakfi İslâm Ansiklopedisi. 30/395-396. Türkiye Diyanet Vakfı İslâm Ansiklopedisi, 2005.

Erdoğan, Mehmet. Fıkıh ve Hukuk Terimleri Sözlüğ̈̈. İstanbul: Ensar Neşriyat, 2005.

İbn Abdilber, Ebû Ömer Cemâlüddîn Yûsuf b. Abdillâh b. Muhammed b. Abdilber en-Nemerî. el-İstizkâr. 9 Cilt. Beyrut: Dârü'1-Kütübi'1İlmiyye, 2000.

İbn Ebî Hatim, Ebû Muhammed Abdurrahman b. Muhammed b. İdris Razî. el-Cerh ve't-ta'dîl. 9 Cilt. Beyrut: Dâru İhyâi't-Turâsi'l-Arabî, 1952.

İbn Hacer, Ebü'l-Fazl Şihâbüddîn Ahmed b. Ali b. Muhammed elAskalânî. Fethü'l-bârî bi-şerhi Sahîhi'l-Buhârî. 13 Cilt. Riyâd: Dâru'sSelâm, 2000.

İbn Hacer, Ebü'l-Fazl Şihâbüddîn Ahmed b. Ali b. Muhammed elAskalânî. Tehzîbü't-Tehzîb. 12 Cilt. Hind: Dâiretü'l-Maârif, 1326.

İbn Hacer, Ebü'l-Fazl Şihâbüddîn Ahmed b. Ali b. Muhammed elAskalânî. Telhîsü'l- habîr fî̀ tahrîc-i ehâdîsi'r-Râfiiyyi'l-kebîr. 4 Cilt. Beyrut: Dârü'l-Kütübi'l-İlmiyye, 1989.

İbn Hibbân, Ebû Hâtim Muhammed b. Hibbân b. Ahmed el-Büstî. Kitâbü's-sikât. 9 Cilt. Haydarabad: Dâiretü'l-Maârifi'1-Osmaniyye, 1973.

İbn Hibbân, Ebû Hâtim Muhammed b. Hibbân b. Ahmed el-Büstî. Meşâhîru ulemâi'l-emsâr. Kahir: Dârü'l-Kütübi'l-İlmiyye, 1959. 
F. ÖZÇELIK / Transaction of Jurisprudential (Fiqhî) Specific Rules with Narrations: Example of Semen as Dirt I 545

İbn Hibbân, Ebû Hâtim Muhammed b. Hibbân b. Ahmed el-Büstî. Sahîhu İbn Hibbân. 18 Cilt. Beyrut: Müessesetü'r-Risâle, 1993.

İbn Kudâme, Ebû Muhammed Muvaffakuddîn Abdullah b Ahmed b.

Muhammed b Kudâme Cemmâîlî Makdisî. el-Mugnî. 15 Cilt. Riyâd: Âlemü'l-Kütüb, 1997.

İbn Mâce, Ebû Abdullah Muhammed b. Yezid er-Rebei el-Kazvînî. Sünen. 5 Cilt. Beyrut: Dâru'r-Risâleti'l-Âlemiyye, 2009.

İbn Mencûye, Ebû Bekr Ahmed b. Ali Muhmamed el-İsfahânî. Ricâlu Sahîhi Müslim. 2 Cilt. Beyrut: Dârü'l-Ma'rife, 1987.

İbn Sa'd, Ebû Abdillah Muhammed. et-Tabakâtü̈l-kübrâ. 8 Cilt. Beyrut:

Dârü'l-Kütübi'l-İlmiyye, 1990.

İbnü'l-Cârûd, Ebû Muhammed Abdullah b. Ali b el-Cârûd. el-Müntekâ mine's-süneni'l-müsnedi an Resulillâh. Beyrut: Kitâbü's-Sakâfiyye, 1988.

İbnü'l-Esîr, Ebü's-Seâdât Mecdüddîn el-Mübârek b. Esîrüddîn Muhammed b. Muhammed eş-Şeybânî el-Cezerî. en-Nihâye fî garîbi'l-hadîs ve'l-eser. 2 Cilt. Beyrut: Dâru'l-Ma'rife, 2006.

İbnü'l-Irâkî, Ebû Zür'a Veliyyüddîn Ahmed b. Abdirrahîm b. el-Hüseyn el-Kürdî el-Mihrânî. Tuhfetü't-tahsîl fì zikri ruvâti'l-merâsîl. Riyad: Mektebetü'r-Rüşd, 1999.

İbnü'l-Mülakkin, Ebû Hafs Siraceddin Ömer b. Ali b. Ahmed. et-Tezkira fíl-fikhi'ş-Şâfî̀. Beyrut: Darü'l-Kütübi'l-İlmiyye, 2006.

İclî, Ebü'l-Hasan Ahmed b. Abdullah b. Salih. Ma'rifetü's-sikât. 2 Cilt. Medine: Mektebetü'd-Dâr, 1985.

İshak b. Râhûye, Ebû Ya'kub İshak b İbrâhim b Mahled. Müsnedu İshak b. Râhûye. 5 Cilt. Medîne: Mektebü'1-Îmân, 1991.

Kahraman, Hüseyin. "Hadislere Göre Cinsel Organa Dokunmanın (Messü'1-Ferc) Abdeste Etkisi". Uludağ Üniversitesi İlahiyat Fakültesi Dergisi 19/1 (01 Ocak 2010), 111-142.

Kahraman, Hüseyin. "Namazda Kahkaha ile Gülmenin Abdeste Etkisi". Uludă̆ Üniversitesi İlahiyat Fakültesi Dergisi 19/2 (01 Haziran 2010), 73-92.

Karâfî, Ebü'l-Abbâs Şihâbüddîn Ahmed b. İdrîs b. Abdirrahmân elMisrî. ez-Zahîre. 14 Cilt. Beyrut: Dârü'1-Garbi'l-İslâmî, 1994.

Mâverdî, Ebü'l-Hasen Alî b. Muhammed b. Habîb el-Basrî. el-Hâvi'l-kebîr fî fikhi mezhebi'l-İmâmi'ş-Şâfî̀. 19 Cilt. Beyrut: Dârü'l-Kütübi'lİlmiyye, 1999. 
546 | F. ÖZÇELIK / Rivayetlerle Fıkhî Zâbıtaların Etkileşimi: Meninin Necaseti Örneği

Mergînânî, Ebû'l-Hasen Burhânüddîn Alî b. Ebî Bekr b. Abdilcelîl el-

Fergânî. el-Hidâye şerhu Bidâyeti'l-mübtedî. 4 Cilt. Beyrut: Dâru'lErkam, 1999.

Mevsıli, Ahmed b Ali b el-Müsenna Ebû Ya'la. Müsnedu Eb̂̂ Ya'la elMevsılî. 13 Cilt. Cidde: Dârü'l-Me'mun li't-Türas, 1989.

Mevsılî, Ebü'l-Fazl Mecdüddîn Abdullāh b. Mahmûd b. Mevdûd. elİhtiyâr li-ta'lîli'l-Muhtâr. 4 Cilt. Beyrut: Dâru'l-Erkam, 1418.

Meydânî, Abdülganî b. Tâlib el-Guneymî el-Meydânî. el-Lübâb fî şerhi'lKitâb. 2 Cilt. Beyrut: Dâru İhyâi't-Turâsi'l-Arabî, 1998.

Mizzî, Ebü'l-Haccâc Cemâleddin Yusuf b. Abdurrahman b. Yusuf. Tehzîbü'l-Kemâl fî esmâi'r-ricâl. 35 Cilt. Beyrut: Müessesetü'r-Risâle, 1980.

Müslim b. Haccâc, Ebü'1-Hüseyin el-Kuşeyri en-Nîsâbûrî. Sahîh. Kahire: Dâru İhyai'l-Kütübi'1-Arabiyye, 1955.

Müzenî, Ebû İbrâhim İsmail b. Yahyâ b. İsmail eş-Şafii. Muhtasarü'lMüzenî fî füru'i'ş-Şâfî̀yye. Beyrut: Dârü'l-Kütübi'l-İlmiyye, 1998.

Nesâî, Ebû Abdirrahman Ahmed b. Ali b. Şuayb. Sünen. Haleb: Mektebetü'1-Metbûâti'1-İslâmiyye, 1986.

Nevevî, Ebû Zekeriyyâ Yahyâ b. Şeref. el-Mecmûu' şerhi'l-Mühezzeb. 20 Cilt. Beyrut: Dârü'l-Fikr, ts.

Özen, Şükrü. "Nehaî". Türkiye Diyanet Vakfi İslâm Ansiklopedisi. 32/535538. Türkiye Diyanet Vakfı İslâm Ansiklopedisi, 2006.

Özşenel, Mehmet. Hanefi Hadis Anlayışının Teşekkülü. İstanbul: M.Ü İlahiyat Fakültesi Vakfı (İFAV), 2. Basım, 2018.

Serahsî, Ebû Bekr Şemsüleimme Muhammed b. Ahmed b. Sehl. elMebsût. 30 Cilt. Beyrut: Dâru'l-Fikr, 2000.

Şâfiî, Ebû Abdillâh Muhammed b. İdrîs b. Abbâs. Kitâbü'l-Üm. Beyrut: Darü'1-Kütübi'1-İlmiyye, 1990.

Şevkânî, Ebû Abdullah Muhammed b. Ali b. Muhammed el-Havlânî. Neylü'l-evtâr şerhu Münteka'l-ahbâr. 9 Cilt. Beyrut: Dârü'1-Kütübi'lİmiyye, 2011.

Şirbînî, Muhammed b. Ahmed el-Hatîb. Muğnî'l-Muhtâc. 6 Cilt. Beyrut: Dâru'l-Kütübi'l-İlmiyye, 1994.

Tahâvî, Ebû Ca'fer Ahmed b. Muhammed b. Selâme b. Abdülmelik b Seleme Ezdî Hacrî Misrî. Şerhu meânî'l-âsâr. 5 Cilt. Riyâd: Âlemü'lKütüb, 1994.

Tehânevî, Zafer Ahmed. Kavâid fî̀ ulûmi'l-hadîs. Beyrut: Dârü'1-Beşâiri'1İslâmiyye, 10. Basım, 2007. 
F. ÖZÇELIK / Transaction of Jurisprudential (Fiqhî) Specific Rules with Narrations: Example of Semen as Dirt I 547

Tirmizî, Ebû Îsâ Muhammed b. Îsâ. Sünen. 5 Cilt. Misır: Mustafa el-Bâbî el-Halebî, 1975.

Ünal, İsmail Hakkı. İmam Ebu Hanife'nin Hadis Anlayışı ve Hanefi Mezhebinin Hadis Metodu. Ankara: Diyanet İşleri Başkanlığı, 3. Basım, 2010.

Yahyâ b. Maîn, Ebû Zekeriyyâ el-Bağdâdî. Târîhu İbn Maîn (Rivâyetü'dDûrî). 4 Cilt. Mekke: Merkezü'l-Bahsi'l-İlmi ve İhyâi't-Türâsi'lİslâmî, 1979.

Zehebî, Ebû Abdillah Şemseddin Muhammed b. Ahmed b. Osman. Mîzânü'l-i'tidâl fî nakdi'r-ricâl. Beyrut: Dârü'l-Ma'rife, 1963.

Zehebî, Ebû Abdillah Şemseddin Muhammed b. Ahmed b. Osman. Siyeru a'lâmi'n-nübelâ. 25 Cilt. Beyrut: Müessesetü'r-Risâle, 1985.

Zehebî, Ebû Abdillah Şemseddin Muhammed b. Ahmed b. Osman. Târîhü'l-İslâm ve vefeyâtü'l-meşâhîr ve'l-a'lâm. 15 Cilt. Beyrut: Dârü'lGarbi'l-İslâmî, 2003.

Zehebî, Ebû Abdillâh Şemsüddîn Muhammed b. Ahmed b. Osmân. elKâşif fì ma'rifeti men lehu rivâye fi'l-kütübi's-sitte. 2 Cilt. Cidde: Dârü'l-Kible, 1992.

Zerkâ, Ahmed. Şerhü'l-kavấ'idi'l-fikhiyye. Dımeşk: Dârü'l-Kalem, 7. Basım, 2007. 